\title{
Cestos, gestos y género, en los azulejos portugueses de la primera mitad del siglo $\mathrm{XX}^{1}$
}

\author{
Baskets, Gestures and Gender in Portuguese Tiles \\ during the first half of the $20^{\text {th }}$ Century
}

\author{
José Luis Mingote Calderón \\ Museo Nacional de Antropología, Madrid
}

A la memoria de François Sigaut

\section{RESUMEN}

Este trabajo ofrece una aproximación parcial al variado contenido de los paneles de azulejos portugueses de la primera mitad del siglo XX que se encuentran en una amplia gama de edificios: estaciones de tren, mercados, plazas, fuentes, comercios, casas particulares, etc. En ellos, las imágenes de los campesinos aparecen filtradas por la óptica de las élites y están categorizadas por la interpretación nacionalista del "pueblo".

La copia de imágenes previas, mayoritariamente fotográficas, transmite una sensación de realismo y de veracidad, plasmada tanto en los elementos materiales como en los gestos de uso de los mismos. Algo que no impide la existencia de una interpretación ideológica de las imágenes. La elección de las escenas pretende reflejar la variedad regional a través de una selección ideológica. En la documentación recopilada priman determinados aspectos frente a otros, destacando el ámbito de la vid, y dentro de él, las vendimias. Junto a ellas, se representa la recogida de la aceituna, ciertos trabajos relativos al cereal, la recogida de algas para abonar los campos y, en menor medida, escenas de mercados o de otro tipo.

Palabras clave: Tecnología agrícola. Campesinado. Ideología. Fotografía. Representación.

\section{SUMMARY}

This paper offers a partial approach to the diverse content of Portuguese tile panels during the first half of the $20^{\text {th }}$ century. Tile panels are found in a wide range of buildings such as train stations, markets, squares, fountains, shops, private homes, etc. showing the image of peasants through an elite perspective. In addition, images are classified according to the nationalist point of view of the "people."

The copy of previous images, mostly photographic ones, communicates a sense of realism and truth which appears well reflected in both in the material elements and the gestures using them. This fact does not prevent the ideological interpretation of the images. The choice of scene themes intends to reflect the existing regional diversity starting from an ideological selection. The data collected

\footnotetext{
${ }^{1}$ Este trabajo fue presentado en los XXXIIIe Rencontres Internationales d'Archéologie et d'Histoire d'Antibes sobre Regards croises sur les outils lies au travail des végétaux, celebrados en esa ciudad en octubre de 2012, aunque no llegó a publicarse en sus Actas.
} 
shows the prevalence of some aspects and puts special emphases on vine issues and, particularly, on grape harvest. Other issues represented include the olive harvest, activities related to cereals, the collection of seaweed for field manuring. Less represented are scenes of markets.

Key words: Agricultural Technology. Peasantry. Ideology. Photography. Representation.

\section{INTRODUCCIÓN}

Este estudio se centra en un corpus iconográfico muy amplio plasmado en paneles de azulejos, que van desde el comienzo del siglo XX hasta mediados de los años 40 , y en los que aparece de forma destacada una imagen del "mundo popular" portugués, campesino, ganadero, pescador... En ellos se muestra, fundamentalmente, una representación selectiva de prácticas de trabajo mayoritariamente preindustrial y de "tipos" que no es nueva en la modernidad, ya que es posible hallar una serie de precedentes recientes que ayudan a entender porqué en un momento dado, a comienzos del siglo XX, estos grupos dan el salto a los paramentos de ámbitos urbanos o de lugares asociados al progreso. Basta mirar a las pinturas costumbristas del siglo XIX o a las postales, revistas y libros ilustrados de finales de ese siglo y, sobre todo, comienzos del siguiente para darse cuenta de ello.

Como he señalado ya en otros textos (Mingote Calderón 2013 y e. p.) las escenas analizadas se encuentran en paneles situados mayoritariamente en estaciones de tren y en mercados municipales, aunque no exclusivamente ya que también las hay en casas particulares, locales comerciales, plazas, fuentes, parques, mataderos e, incluso, en ayuntamientos. Suelen aparecer en conjuntos de varios paneles que, en bastantes ocasiones, llegan a alcanzar un volumen importante que puede rondar el medio centenar. El nacionalismo, el turismo y la intervención de las élites locales —culturales, políticas y económicas - ayudan a comprender muchas de las claves que explican los motivos representados y, sobre todo, la presencia de un "pueblo" campesino que se muestra como "esencia de la nación" desde el siglo XIX. Al igual que sucede con todas las producciones mencionadas, los paneles de azulejos están producidos por un grupo que debemos calificar de elitista. Por tanto, lo que nos refleja esta iconografía no son, ni pueden ser en esos momentos, "autorrepresentaciones" de los propios grupos, sino representaciones burguesas de un "pueblo" mitificado.

Salvo el libro de R. Salinas Calado y P. Vieira de Almeida (2001), en el que se estudia el "patrimonio azulejar" en las estaciones de tren, y el de J. Hengel y V. Hustinx (1987) que aborda estos azulejos desde una perspectiva más general, este corpus no ha merecido la atención detallada de la investigación portuguesa. Para explicar esta situación, quizá haya que acudir a la opinión emitida por el prestigioso historiador del arte José-Augusto França (1992: 280), para quien las estaciones de los años 20 debían satisfacer un modelo arquitectónico "común e corrente" que variaba sólo en el tamaño y que se caracterizaban por sus "banais paneis de azulejos de cartaz local. Evidentemente, se trata de una opinión poco compartible, porque el análisis cultural de esos banales paneles produce un más que interesante resultado científico ${ }^{2}$.

\footnotetext{
${ }^{2}$ Esta opinión cabe entenderla desde una perspectiva de historiador del arte que se interesa por las iniciativas modernizadoras en el arte portugués, algo a lo que no responden estos paneles. Quizá
} 


\section{LA REPRODUCCIÓN DE IMÁGENES PREEXISTENTES}

Como paso previo al análisis de lo que se documenta en los azulejos, a través de las personas y los objetos allí dibujados, es necesario aludir a la forma de representar estos trabajos agrícolas desde una perspectiva gráfica, dado que la práctica totalidad de los mismos tiene un origen fotográfico. No voy a extenderme sobre la estrecha relación entre fotografía y pintura de azulejos ${ }^{3}$, pero hay que decir que a pesar de haber sido señalada — por ejemplo, por parte de R. Salinas Calado y P. Vieira de Almeida (2001: 21, 24, 34, $46,47,55,66,78$ y 112)—, no se ha profundizado en ella.

Partiendo de su origen fotográfico, las imágenes analizadas son realistas en el sentido en que se consideró realista la fotografía en esos momentos. Una característica que se puede encontrar en múltiples aspectos que cabría llamar materiales, en sentido amplio, ya que las escenas agrícolas pueden estar reflejando la realidad a través del tipo de trabajo, los aperos empleados, la forma de ir vestido o la presencia de una organización social jerarquizada ${ }^{4}$. Se trata de un realismo evidente a pesar de que no se pueda decir que tenga un carácter absoluto porque se ve afectado por la intervención que implica la selección de escenas, las actitudes de preparación que tienen muchas de las tomas fotográficas originales o la elección de imágenes alejadas del lugar donde se reproducen en azulejos.

Una primera reflexión sobre la forma de representar las imágenes lleva a constatar grandes variaciones entre artistas e, incluso, entre obras de una misma persona, siendo algo evidente la distinta calidad de los dibujos. Como consecuencia de ello, encontramos una amplia diversidad en cuanto a lo que cabría denominar resultados artístico-técnicos. Las importantes diferencias en relación con el aparente realismo de las imágenes, se asocian también al estilo en que están dibujadas. Junto a aquéllas que reflejan la reproducción fiel de una fotografía, hay otras que, por su estética, presentan un cierto aire infantil. Sin embargo, hay que decir que tomar esta afirmación de forma muy radical puede inducir a errores.

Por otro lado, hay que distinguir entre aquellas escenas que podríamos llamar principales y las que son sólo un motivo de relleno, situadas en un segundo plano. Las posibilidades de las representaciones varían desde el detenimiento en los pequeños detalles hasta un mero esbozo (figs. 1 y 2). En relación con estos hechos, aunque no siempre asociado a ellos, encontramos distintos grados de detallismo a la hora de dibujar los objetos. Todo esto conduce, en ocasiones, a suscitar algunos problemas de interpretación.

el peso de su opinión hace que otros autores no les dediquen prácticamente ninguna atención, como se comprueba en el catálogo sobre los azulejos del siglo XX (VV. AA. 2000: 21-22), en el que se menciona a Jorge Colaço, autor de la decoración de la monumental estación de São Bento, en Oporto, y otras dos estaciones más, alentejanas (en realidad, este autor decora cinco estaciones en el Alentejo: Marvão-Beirá, Castelo de Vide, Vale do Peso, Beja y Évora, y muchísimas otras obras). Asimismo, se cita a Leopoldo Battistini, sin entrar a detallar su trabajo. Estas imágenes son calificadas por J. Meco (1993: 246-248) como "azulejaria historicista e nacionalista.

3 A este tema he aludido en otros trabajos (Mingote Calderón 2013 y e.p.). Además estoy preparando un estudio monográfico sobre la relación entre los modelos usados y las copias producidas en los paneles, por lo que ahora solo indicaré algunos aspectos, que desarrollo con mayor amplitud en ese texto.

${ }^{4}$ Es posible documentar bastantes escenas en las que está presente el dueño o el encargado de los trabajadores, vestido de manera diferente a ellos y en actitudes claras de diferenciación respecto al resto de las personas. 


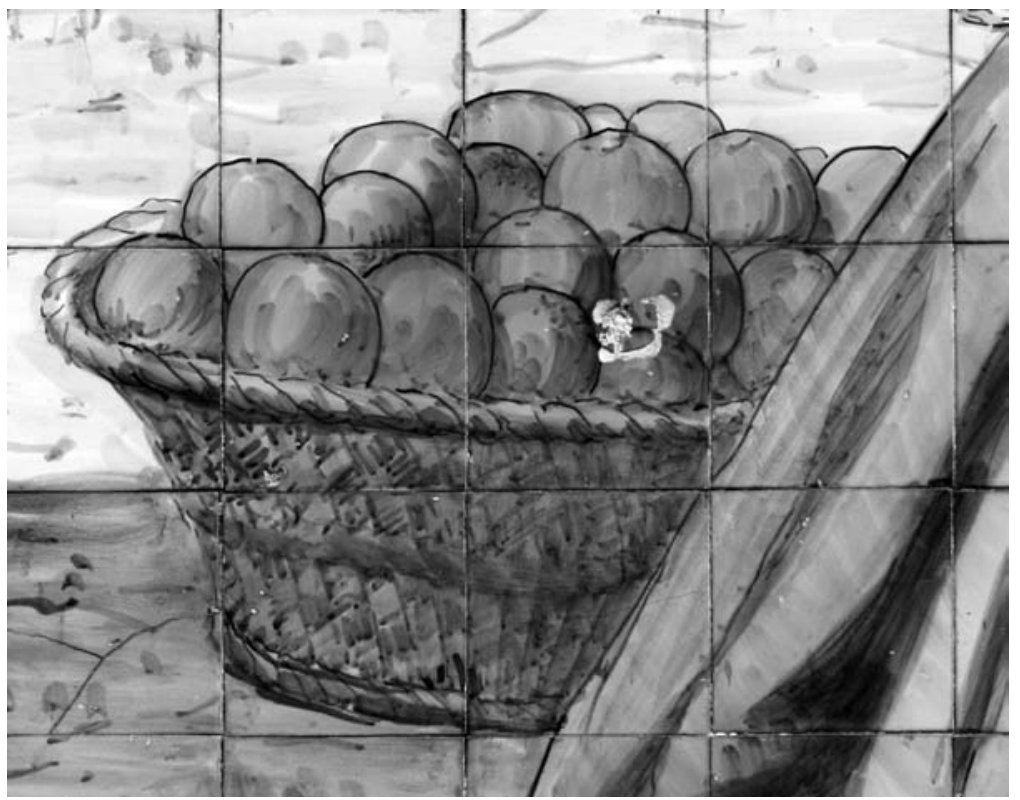

Figura 1.-Cesto con cierto detalle, en una escena de primer plano. Praça da República o Rossio, en Viseu. Joaquim Lopes (1931). Fábrica do Agueiro, Vila Nova de Gaia. Fotografía: José Luis Mingote Calderón, 2010.

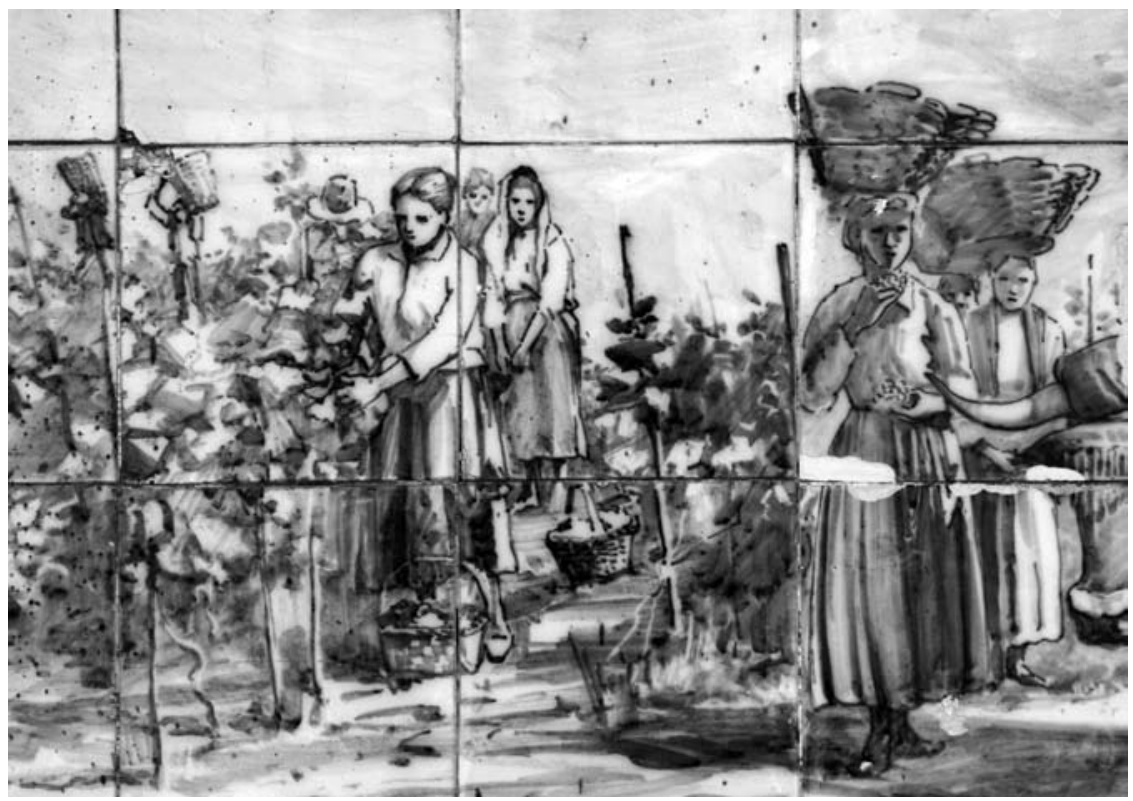

Figura 2.-Escena de vendimia, con poco grado de detallismo. Nótese la diferencia de tamaño con la figura anterior. Estación de Mondim de Basto. Gilberto Renda (S. f.). Sant'Anna, Lisboa. Fotografía: José Luis Mingote Calderón, 2012. 
A veces, las primeras impresiones sobre el escaso realismo de ciertas imágenes no siempre son correctas. Un ejemplo claro lo encontramos en la estación de tren de Leça do Balio, al norte de Oporto, donde se representa a un grupo de trabajadores llevando los cestos de vendimia característicos del Duero. El grupo aparece de manera algo extraña, dado que lo normal es encontrar una fila india de hombres, cargando los cestos tras la cabeza, pudiendo estar precedidos por algún músico, como ocurre aquí (fig. 3). El aparente desorden no es debido a una visión imaginativa o irreal, sino que se explica por una elección artística de su autor, Leopoldo Battistini. Este, contra lo que pudiera parecer a primera vista, ha copiado una fotografía de la

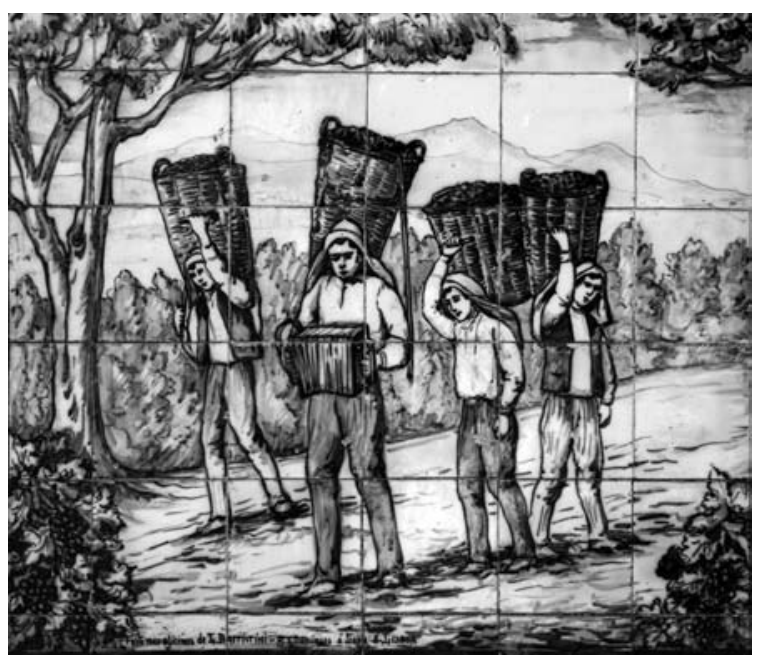

FiguRA 3.-Hombres transportando la uva. Estación de Leça do Balio. Leopoldo Battistini (S. f.) Constância, Lisboa. Fotografía: José Luis Mingote Calderón, 2012.

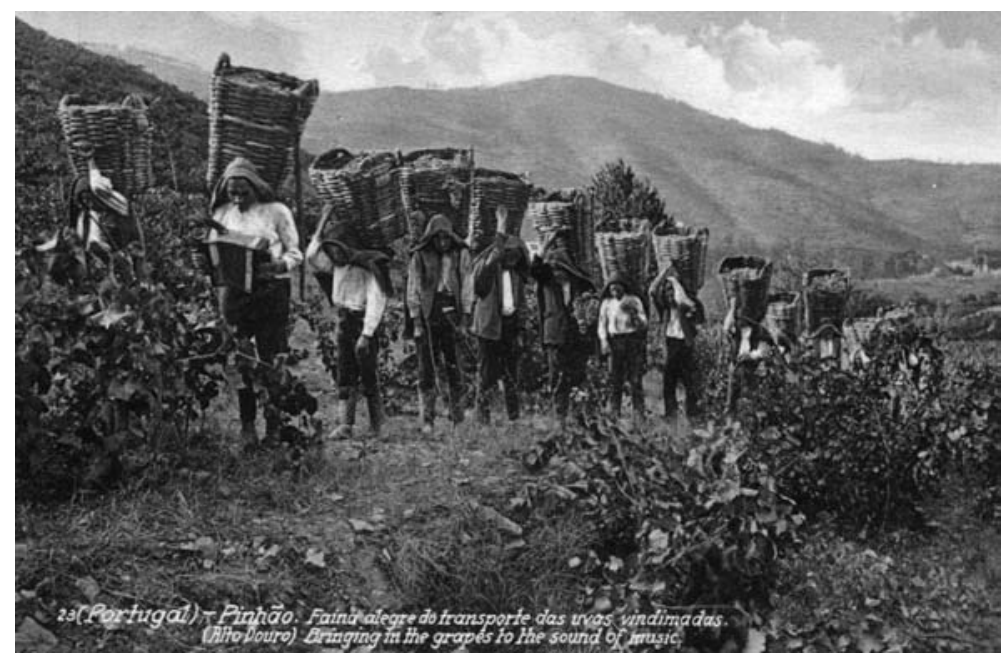

Figura 4.-Porteadores de cestos de vendimia en Pinhão, en el Duero. Postal editada por C. Consell de Vasconcellos. La fotografía original es de Foto Beleza, aunque no se indique en la postal. 
que ha seleccionado a una serie de porteadores, suprimido a otros y modificado radicalmente el paisaje, como se comprueba acudiendo a una postal que localiza la vendimia en Pinhão —en pleno Duero y alejado más de 80 kilómetros de Leça do Balio-, y en la que es posible apreciar que la estática fila de porteadores es mucho mayor, como es lo habitual (fig. 4). La alteración producida en el panel de azulejos, en relación con la colocación y eliminación de los porteadores, genera una composición bastante extraña que lleva a pensar en algo irreal. No obstante, como se deduce tras esta comparación, la primera sensación ante el panel no deriva del estilo, sino de la manera en que el autor convirtió una imagen fotográfica en un dibujo, utilizando una total libertad.

Un aspecto interesante de la búsqueda de imágenes fotográficas que sirvieron de base a los dibujos de los paneles de azulejos es el posible desfase cronológico entre original y copia. El recurso a la fotografía como modelo aparece desde los primeros momentos, como vemos en los paneles de la estación de Aveiro, en la que se representa la recogida del sargazo en el río Vouga, en concreto en Eixo (fig. 5) que tiene su origen en una postal, que representa a lavradores-moliceiros del lugar citado, cargando algas 5 .

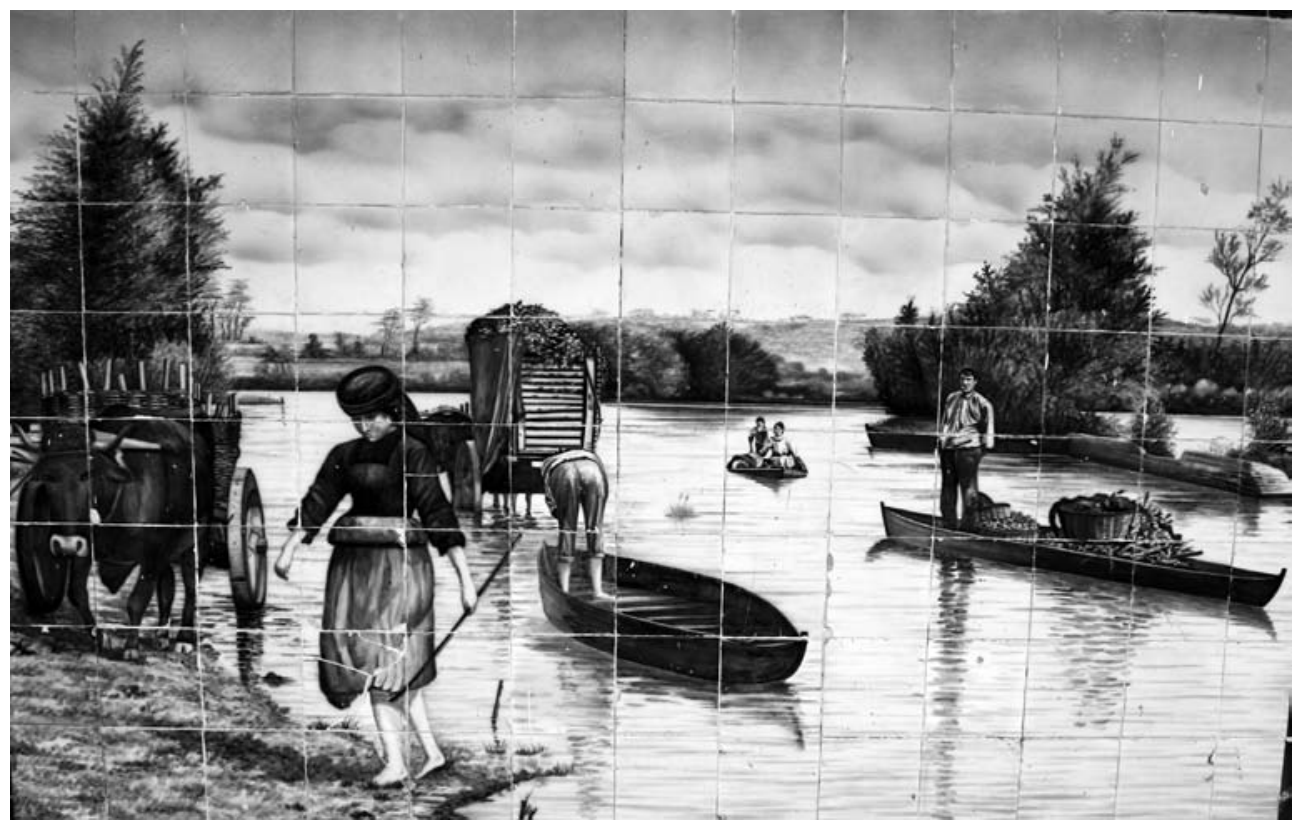

FiguRA 5.— "Trecho do Vouha - Eixo". Escena de recogida de sargazo, en Eixo. Estación de Aveiro, Licinio Pinto (1916). Fonte Nova, Aveiro. Fotografía: José Luis Mingote Calderón, 2011.

${ }^{5}$ La postal se editó en esa localidad, y hay un ejemplar circulado, en enero de 1913, que se puede ver en el trabajo de F. M. Vicente de Sousa y J. M. Neto Jacob (1985: 155-156, nㅡㄹ 1185) sobre las postales portuguesas del primer cuarto del siglo XX. Por lo tanto, en 1916, Licinio Pinto recurre a una imagen relativamente reciente, para reproducirla en la estación. 
Un ejemplo que nos muestra un mayor desfase cronológico entre el original y la copia se ve en una escena de vendimia de la estación de Pinhão, en la que una mujer vacía el contenido de un cesto pequeño para rellenar otro mayor, situado junto a otros, característicos de las vendimias del Duero, similares a los que hemos visto en Leça do Balio. De este panel de azulejos, que J. Oliveira realiza en 1937, resulta interesante el pie de imagen que se ha escogido: "Cestos tipicos do Douro", ya que denota un afán por presentar una imagen de lo pintoresco local, de lo "típico", que se define de forma expresa como tal (fig. 6). La fotografía que ha servido para trasladarla a los azulejos aparece ya reproducida en el tomo dedicado a la Agricultura, editado con motivo de la Exposición Iberoamericana de Sevilla, de 1929 (fig. 7) (Rasteiro 1929: $35)^{6}$. En esta ocasión, la copia que se hace es fiel, sin introducir cambios, salvo por un detalle: la foto original está tomada en Peso de Régua, a unos 30 kilómetros de la estación de Pinhão, según consta en la información existente en una postal moderna. La escena, aunque no se diga en el libro mencionado, es una fotografía de la Casa Alvão, lo que es una constante en esta estación?.

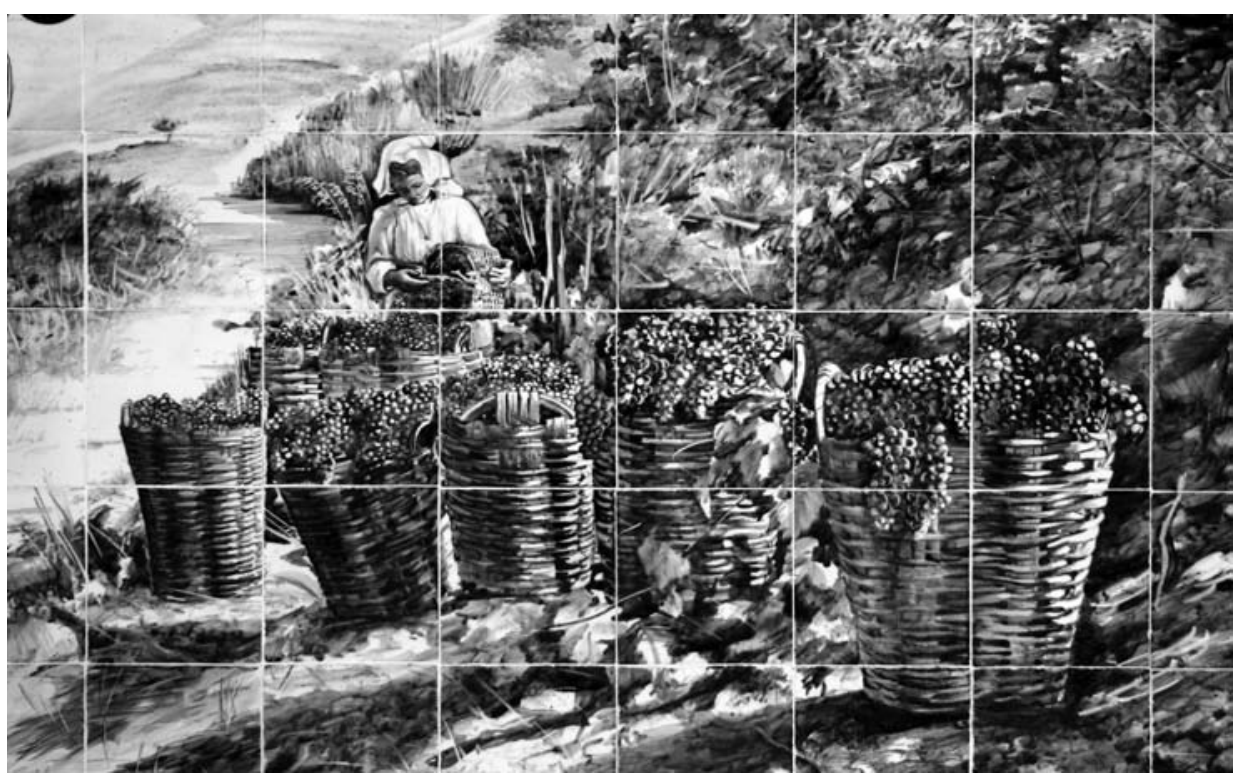

Figura 6.— Cestos típicos do Douro". Estación de Pinhão. J. Oliveira (1937), Fábrica Aleluia, Aveiro. Fotografía: José Luis Mingote Calderón, 2012.

${ }^{6}$ Poco después, aparece también en Le Portugal et son activité économique (VV. AA. 1932: 91), editado por el Ministerio de Asuntos Exteriores portugués con una carga propagandística evidente.

7 También se copian las imágenes en las que aparecen personas, un barco rabelo y diversos paisajes. La Casa Alvão -Domingos Alvão (1872-1946) y Álvaro Cardoso de Azevedo (1894-1971)realiza una importante documentación gráfica por encargo del Instituto do Vinho do Porto (donde se encuentran los originales), en los años 40 del siglo XX, en la que recogen quizá alguna imagen anterior. Las imágenes de personas, en Pinhão, pertenecen al segundo de los fotógrafos citados. Sobre D. Alvão se puede ver el estudio de F. A. Cordeiro de Figueiredo (2000: 279-280), quien cita un trabajo de S. Lage sobre esta estación, que no he localizado. 


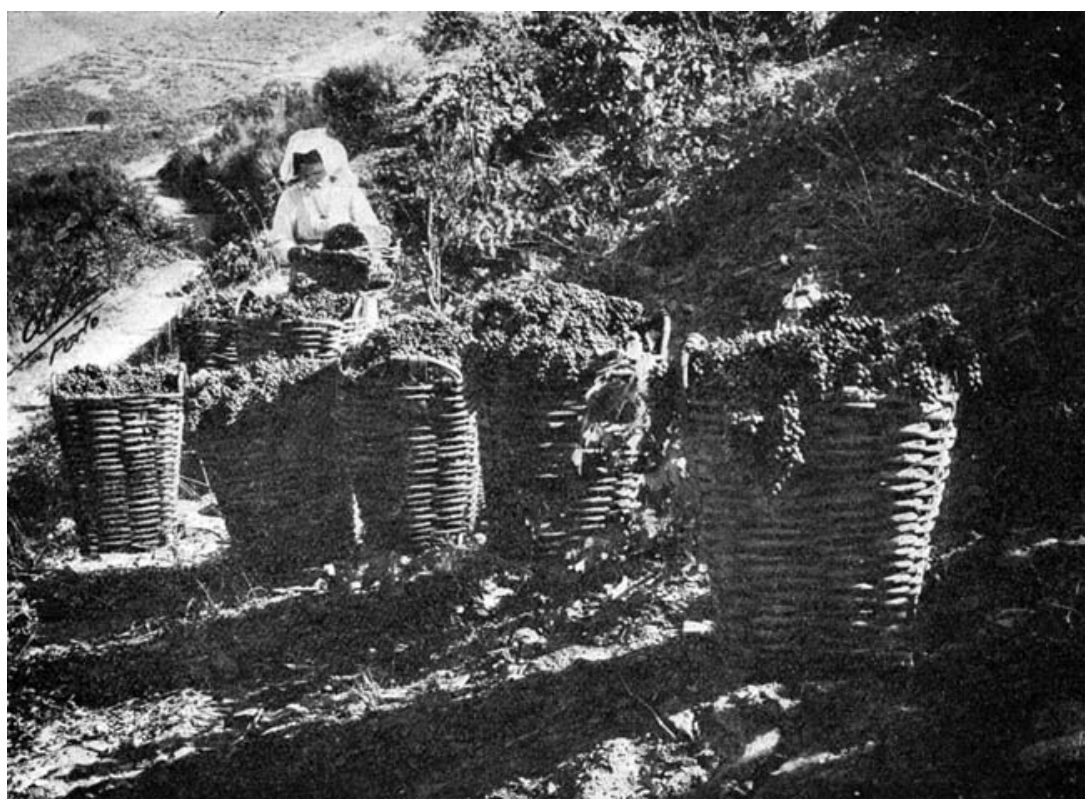

FIgURA 7.-Douro. Enchendo os "poceiros". Joaquim Rasteiro, A Agricultura, Exposição Portuguesa, en Sevilha, 1929. Fotografía Casa Alvão, no mencionada expresamente.

Estas breves alusiones, que podrían ampliarse a otros muchos ejemplos, sirven para ver que el recurso a imágenes preexistentes de buena parte de la iconografía de los paneles de azulejos. Se acude a fotografías que se encontraban publicadas en libros, revistas o en postales, aunque es muy posible que, una vez localizadas, el dibujante trabajara con una copia mejor que la que aparece en esos soportes. Como consecuencia de ello, hay que afirmar que no siempre nos hallamos antes obras coetáneas a la realización de los azulejos, pudiendo darse el caso de que el original tenga más de veinte o treinta años de antigüedad. También es importante recalcar que, junto a la representación bien localizada de algunos elementos, encontramos el uso de imágenes que reflejan una realidad comarcal, no local. En este sentido, las imágenes pueden no alejarse excesivamente de lo que se podía ver en el lugar donde aparecen, pero no cabe pensar que los paneles de azulejos remitan siempre al lugar concreto donde se encuentran colocados.

\section{EL CONTENIDO DE LAS IMÁGENES DESDE UNA PERSPECTIVA ETNOLÓGICA}

De los muchos temas con contenido etnológico que se pueden analizar en estos paneles voy a centrarme en uno muy concreto: aquellas escenas en que se encuentran presentes objetos de fibras vegetales con un uso fundamentalmente agrícola.

La cestería muestra una serie de características particulares respecto a otros objetos de uso agrario. Estos rasgos tienen que ver con la variedad de tamaños de tipologías concretas, que hacen que los cestos cambien de función sin hacerlo de forma; asi- 
mismo, existe una gran variación terminológica que permite constatar nombres iguales para piezas formalmente distintas. Por otro lado, también es posible ver cómo las piezas y las técnicas de fabricación se difunden a través de la venta en las ferias y mercados o de la deslocalización de los propios cesteros, ya sea para trabajar fuera para un patrón o por el cambio de localidad. Baste citar dos ejemplos recogidos por F. Galhano en su estudio sobre la cestería de Entre Douro-e-Minho; este autor anotó que de Arnoso — al sur de Braga- salían cestos para Oporto y los concejos vecinos, sobre todo las gigas de lavoura, que se vendían en las ferias de Maia; los gigões para comercio e industria; las gigas de regateira, para las vendedoras de legumbres (mucho más bajas); y las "cestas para sementeiras, adubos", que tienen un asa en arco. Asimismo, al describir el tipo cepões (con fondo redondo, boca cuadrada y de muy poca altura) indicó que las cestas para simiente, abono, frutas y trabajos caseros, fabricadas en Ponte de Lima (pequeñas y de tiras largas o estrechas, o proporcionalmente más altas, a las que se coloca un asa en arco) eran vendidas en Viana do Castelo, donde pedían una menor altura para algunos fines (los de feria), y se usaban por la costa hasta Neiva y Esposende (Galhano 1961-1962: 266-267, 277 y 278).

En otro orden de cosas, desde hace mucho tiempo, los investigadores han hablado de la polifuncionalidad de muchos tipos de cestos, lo que conviene tener presente a la hora de analizar las imágenes. La consecuencia es que vamos a ver cestos "que se han usado en" y no cestos que sean "exclusivamente para". Los ejemplos etnográficos en los que se constata esta polifuncionalidad son muchísimos, por lo que ahora seleccionaré sólo algunos. El primero procede de E. Ribeiro (1930: 44), quien nos dice que el cabanejo — un cesto de mimbre, con dos asas, usado en el Alentejosirve tanto para la vendimia como para la recogida de aceituna ${ }^{8}$.

Entre los muchos casos citados por M. H. Santos Silva (1961: 78-79), recojo el variado uso de los cestos de canastrel, en Ponte do Sor, localidad antiguamente ribatejana y ahora alentejana; se trata de cestos con un asa vertical que se usaban en la vendimia, la recogida de la aceituna, el transporte de comida y en la siembra, cuando era hecha por mujeres (frente al saco usado por los hombres).

Otro ejemplo, localizado en Alvite y Montemuro (Beira Alta), es el de la cesta de palba, con forma troncocónica invertida y con asa de madera, que se utilizaba para varias funciones: sembrar, aventar el grano, transportar frutas o verduras y, finalmente, para llevar la comida al campo, como señaló B. Kuoni (1981: 84 y 88). Esta autora, comentó que los cestos del norte de Portugal se asemejan a los gallegos: fondo cuadrado, boca redonda, paredes rectas y aros cosidos o bordados, con dos asas laterales - los mayores - o asa en arco, — los menores_, y que estos, además de usarse en la recolección de frutos y la vendimia, se usaban en la siembra (Kuoni 1981: 137 y 139). Asimismo, según esta investigadora, desde Oporto a Coímbra, aproximadamente, y hasta Viseu y Castelo Branco, los cestos tipo canastra servían para todo:

\footnotetext{
${ }^{8}$ Este autor señala también que para la vendimia o la recogida de la aceituna, en el Alentejo, las mujeres usan una cêsta con el cuerpo troncocónico y un asa central vertical, y que estaba hecha de ormes, olmos, cognassiers, membrillos, o frênes, fresno. En su imagen, el cesto parece de mimbre (Ribeiro, 1930: 44-45). Por su parte, M. H. Santos Silva (1961: 80) señala que, en la zona alentejana de Elvas, Estremoz, Aviz, Portalegre y Arraiolos, el cabanejo es un cesto pequeño y que el de mayor tamaño se denomina fanga.
} 
trabajos agrícolas, repartir pan, vender pescado, lavar ropa y como cuna; estaban hechos de castaño solo o combinado con acacia. También había cestas con asa central para llevar la comida al campo, sembrar, plantar patatas, vendimiar, recoger la aceituna de vareo y otros usos (Kuoni 1981: 140-141). Un último dato, procedente esta vez de Penafiel (al NE de Oporto), lo aporta T. Soeiro (2008-2009: 263), cuando señala la polifuncionalidad de los gigões — grandes cestos de madera con dos asas y forma más o menos troncocónica-, usados para recoger hojas y que también servían para arrumar, organizar, el maíz, no pudiendo ser transportados en esta segunda faceta ya que su capacidad era de más de seis alqueires ${ }^{9}$.

En relación con los cestos que vemos en los paneles de azulejos es necesario decir también que bastantes de ellos aparecen sin uso o sin ninguna carga ${ }^{10}$, por lo que pueden ser transportados de una manera también tradicional, pero sin relación con la forma de llevarlos una vez cargados. Los cestos vacíos se llevaban bajo el brazo, como indica T. Soeiro (2008-2009: 261) en alusión a los açafates que se empleaban, entre otras cosas, para ir a la feria o a la tienda o para llevar la comida a las personas que trabajaban en el campo, transportándose, entonces, sobre la cabeza.

\section{LOS CESTOS Y EL CUlTiVO DE LA VIÑA}

Voy a comenzar, dada su importancia numérica, por los cestos relacionados con la viticultura. Además del elevado número de escenas en las que se representa la vendimia, esta aparece cargada de una complejidad técnica que afecta directamente al uso de los recipientes. Como es bien sabido, la recogida de los racimos suele hacerse en un tipo de cesto de tamaño pequeño que, a su vez, será descargado en otro mayor que acabará o bien sobre un carro, sobre el armazón del mismo o en cestos llevados por caballerías. En las escenas vistas, no aparece este último sistema que puede requerir cestos específicos, que analizó F. Galhano (1966), mientras que sí encontramos soluciones intermedias como el cargar grandes cestos de transporte colocándolos en medio del viñedo y no en su límite, fuera de él.

Los gestos asociados a los pequeños cestos de vendimia son escasos, ya que sólo aparecen en la estación de Canas-Felgueira, en la que vemos a dos mujeres llevando, en el brazo, un cesto con asa central, a la vez que vendimian (fig. 8). En ocasiones, los cestos de pequeño o mediano tamaño aparecen colocados sobre el suelo, sin que se muestre cómo se transportan, o bien en el momento de ser llevados a cestos mayores o cuando son vaciados en ellos. En Pinhão, podemos ver pequeños cestos colocados en el suelo y esos mismos cestos sirviendo para trasvasar a otros

\footnotetext{
${ }^{9}$ En Entre Douro-e-Minho el alqueire ha tenido una capacidad de entre 17 y 19,3 litros. En otras zonas, más al sur, puede bajar hasta 13,1 litros. La utilización de los cestos como unidad de medida ha sido resaltada por M. H. Santos Silva (1961: 122-124, y 70, 81, 83 y 118) con amplia información.

10 En esta situación, además de los que citaré por encontrarse en trabajos analizados posteriormente, se encuentran ejemplos en la estación de Aveiro y en la fuente del Parque Municipal de la misma ciudad, en relación con los trabajos de la pescadera, en la primera, y con salineras en la segunda. Asimismo, aparecen distribuidos por los muelles, a la espera de llenarlos de pescado, en el Mercado do Livramento de Setúbal.
} 
mayores; en el segundo caso una mujer, que va por un camino, lleva en su brazo izquierdo un pequeño cesto para descargar en otro mayor, donde otra mujer ya está descargando el suyo (fig. 9).

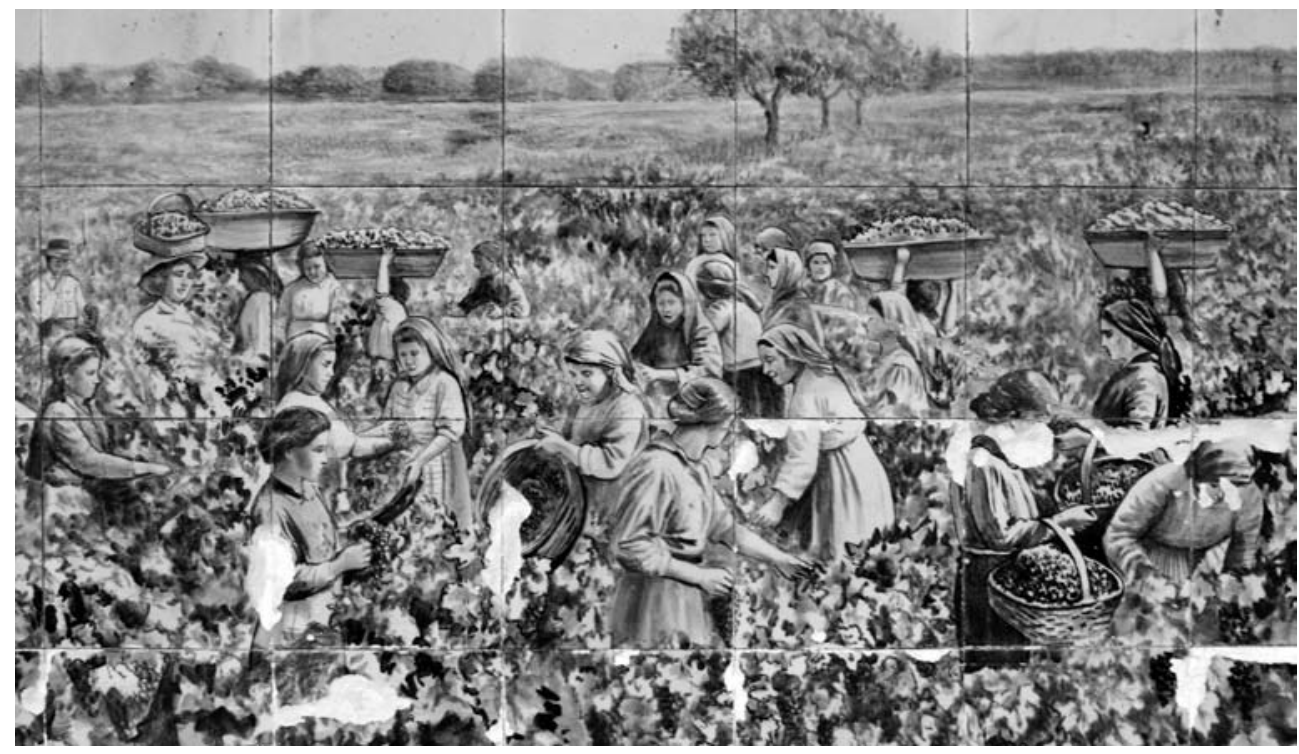

FIGURA 8.- "Vindima”. Estación de Canas-Felgueira. Francisco Pereira y Licinio Pinto (S. f.). Outeiro, Águeda. Fotografía: José Luis Mingote Calderón, 2013.

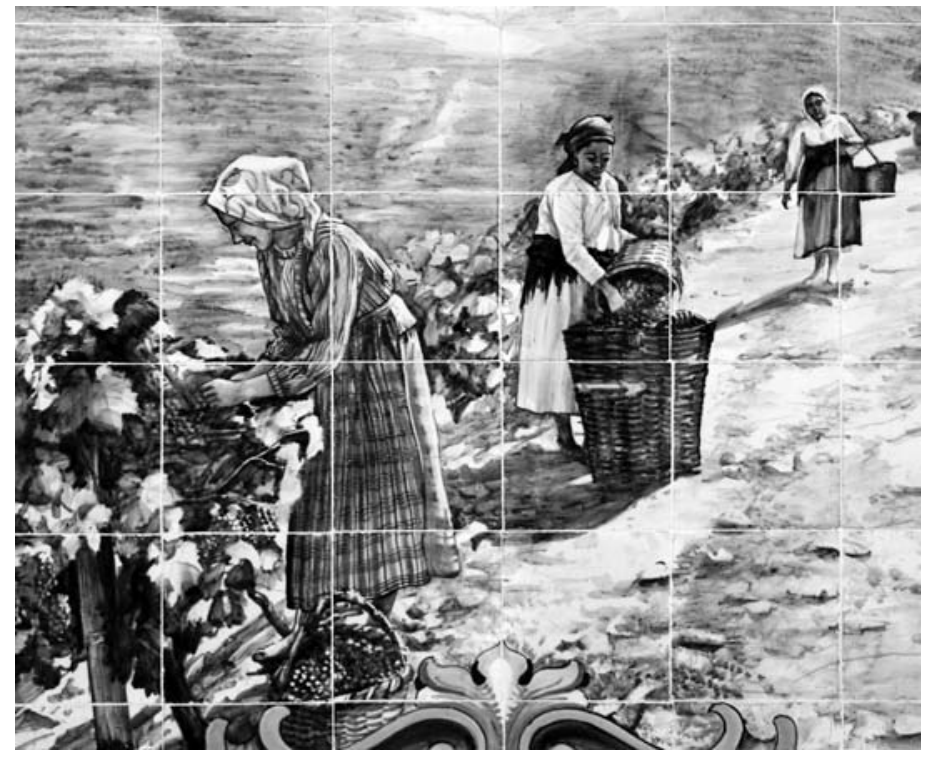

Figura 9.— "Vindimando». Estación de Pinhão. J. Oliveira (1937). Fábrica Aleluia, Aveiro. Fotografía: José Luis Mingote Calderón, 2012. 
Además, en otra escena de la misma estación, ya vista, una mujer llena uno de los cestos grandes que se encuentra junto a varios más, a la espera de su transporte en carro. Otras escenas de vendimia en las que vemos los cestos en los que echar las uvas colocados en el suelo, o apoyados en algún sitio, se encuentran en las estaciones de Nelas, Oporto São Bento, São Mamede de Infesta y el Mercado do Livramento de Setúbal. Un ejemplo, en el que creo que prima la pose sobre el gesto de trabajo, es el de Pinhal Novo, donde una mujer sujeta un cesto apoyándolo en su cadera, a pesar de tratarse de un gesto claramente femenino de transporte, ya que el cesto está cargado de racimos. En Mondim de Basto (ver fig. 2) podemos ver las distintas formas de transporte, en función del género y del tipo de cesto utilizado, en la misma escena; aquí, la vendimia es realizada por mujeres que tienen los cestos en el suelo, junto a ellas, y al lado aparecen otras cargando cestos sobre la cabeza, mientras que, al fondo, dos hombres los cargan sobre el hombro y, quizá, sobre el cuello.

Los cestos de traslado al carro pueden ser llevados indistintamente por el hombre y por la mujer, coincidiendo en escasísimas ocasiones el gesto de transporte, ya que se aprecia una clara dicotomía: el hombre transporta el cesto en el hombro o en el cuello, con la trouxa que tira de la cabeza (a la manera del Duero), mientras que la mujer lo lleva sobre la cabeza. Una de las mujeres que aparecen en la estación de São Bento, en Oporto, y otra en el Mercado de Setúbal, llevan un cesto sobre el hombro frente a lo que es la norma, incluso, en la misma escena portuense, en la que otras mujeres lo llevan sobre la cabeza ${ }^{11}$. En algún caso, como vemos en el Mercado municipal de Santarém o en la estación de Bombarral, el cuévano puede ser de madera y no de cestería. En el segundo caso, se ve el gesto interesante de cómo se ayuda a cargarlo en el hombro. A pesar de lo dicho, en el mercado citado, vemos el acarreo con cestos de mimbre en otra escena diferente, que copia una fotografía previa en la que se indica que se está descargando la uva en la bodega Charnixe, nombre que figura en la cuba que hay sobre el carro $^{12}$. También, vemos el acarreo sobre la cabeza en Lisboa —en el Palacio Alverca / Casa del Alentejo-, o en el Mercado municipal de Vila Franca de Xira y en la estación de la misma localidad. El gesto de coger un cesto por las asas, entre una mujer y un niño, lo he documentado solamente en la Pastelería 1800, de Lisboa (fig. 10).

En la escena de São Mamede de Infesta aparece una vendimia en viñas asociadas a árboles, en la que un hombre echa racimo en un cesto de mediano tamaño, con dos asas, que sujeta una mujer que lo apoya en la escalera en la que se coloca el vendimiador. Otros cestos similares, colocados en el suelo, rodean una cuba en la que se pisará la uva.

Posiblemente sean las escenas centradas en el Duero y vinculadas al vino de Oporto, las que muestren una mayor originalidad en cuanto a los gestos, que se han convertido en un icono de la zona al igual que los propios cestos; algo asumido ya en la década de 1930, como se ha visto. Tanto en Pinhão como en Pocinho — donde también se copia una fotografía de la Casa Alvão— aparecen las características filas

\footnotetext{
${ }^{11}$ Aquí, como en São Mamede de Infesta, se representa la vendimia de vides asociadas a árboles; es decir, la forma característica del Miño. Ambas estaciones están en la línea del Miño.

${ }^{12}$ Cuando es copiada tiene más de 30 años, ya que se documenta en B. C. C. da Costa y D. L. de Castro (1900: frente a la p. 398).
} 


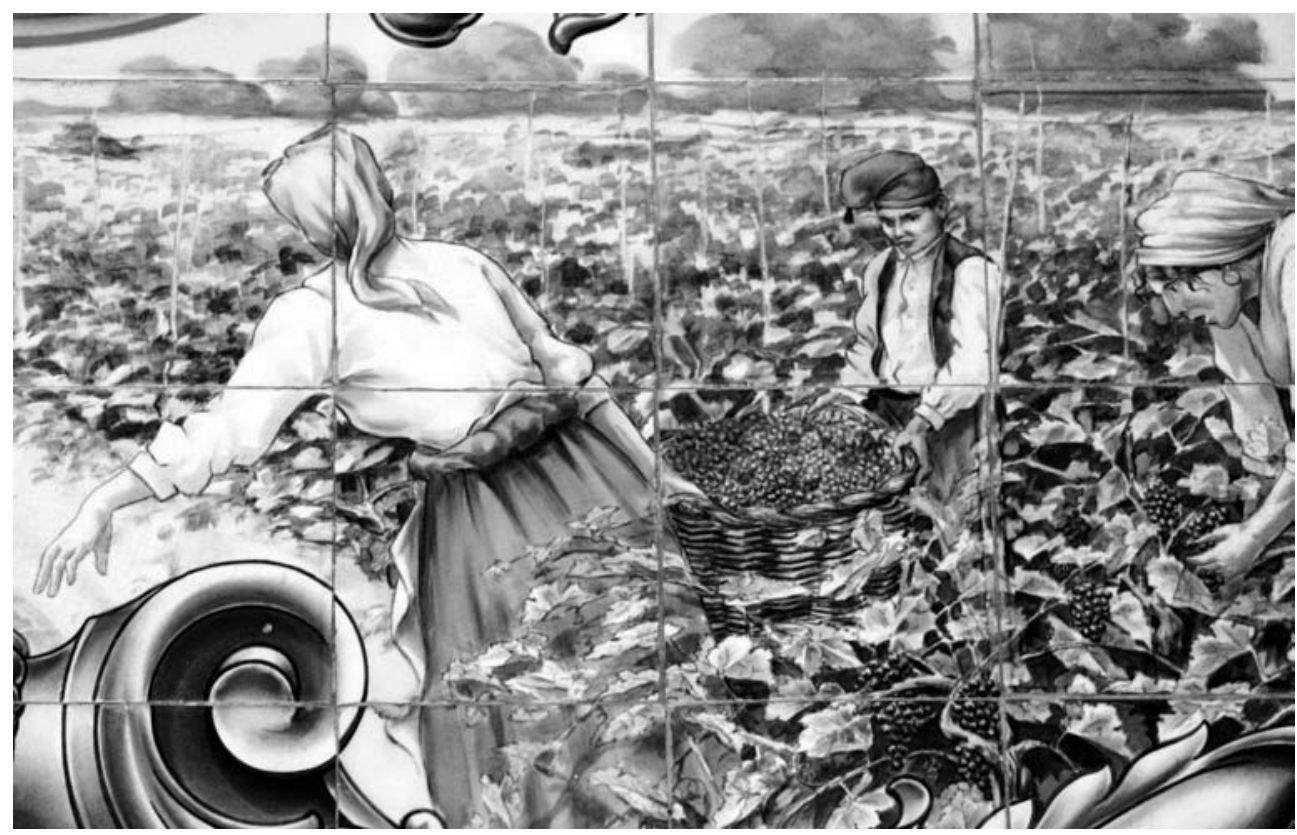

Figura 10.-Transporte de uva. Pastelería 1800, en Lisboa. Sin autor (1924). Sin fábrica. Fotografía: José Luis Mingote Calderón, 2014.

de hombres, con los grandes cestos cargados sobre las trouxas y sujetos del asa central, que siguen el sinuoso perfil de los caminos de los viñedos del valle del Duero, vigilados por el capataz. Con menos claridad, dado el número de personas representadas, se ve esta disposición en Lamego, en un banco del Parque da República, mientras que en Leça do Balio, como se ha indicado, encontramos la presencia de un acordeonista que va cargado con un cesto $^{13}$. E. Veiga de Oliveira et alt. (1983: 337) anotaron que el característico "grande cesto vindimeiro" presenta tres asas y que se lleva sobre la trouxa, colocada sobre la cabeza, y se sujeta de la tercera asa, con la mano, o con un gancho agarrado al borde; son de fondo cuadrado y boca redondeada, y se usan en la zona de Vila Real y en el Duero, hasta la frontera norte, en la zona de Chaves y Mirandela ${ }^{14}$. Los ganchos pueden apreciarse en la escena de Pinhão en la que los cargadores descansan junto a los cestos llenos de uva (figs. 11 y 12).

En otro de los bancos del Parque de Lamego, se reproduce una escena de pisado de la uva en el lagar, en la que aparece una mujer con un cesto de mimbre, troncocónico y con dos asas, vaciándolo junto a uno de los grupos que están trabajando y que llevan una serie de instrumentos musicales.

${ }^{13}$ Algo que es posible ver repetidamente en las imágenes de la Casa Alvão, en las que el conjunto musical puede completarse con otra persona que toca un bombo o, con el grupo descansando, con alguna guitarra portuguesa o un acordeón.

${ }^{14}$ Según B. Kuoni (1981: 139), entre Vila Real y Peso de Régua, la carga de este cesto vindimeiro puede alcanzar unos $60 \mathrm{~kg}$, siendo costumbre que el vendimiador aportara su propio cesto, que solía llevar marcas de propiedad. 


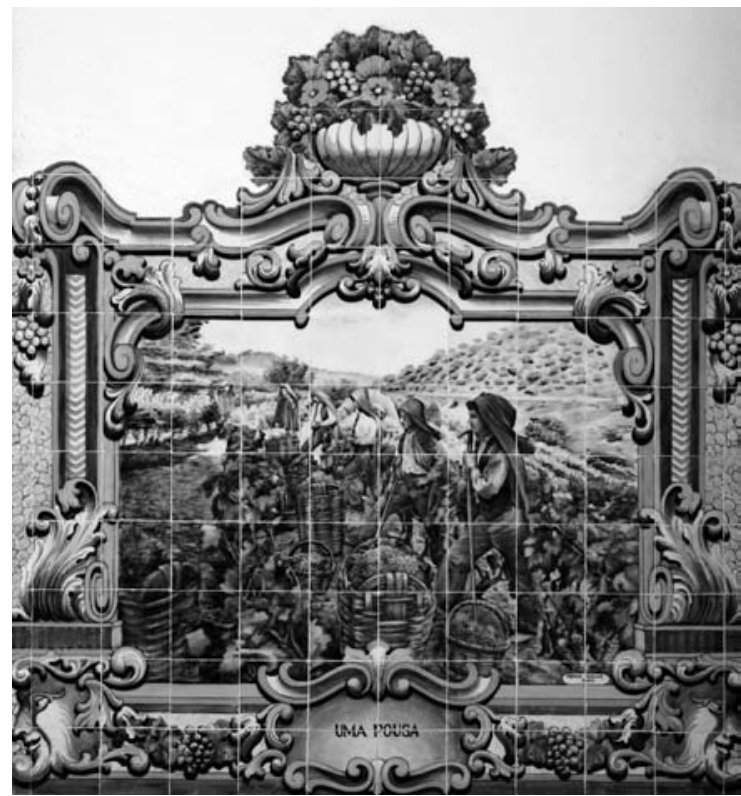

Figura 11.—Uma pousa». Estación de Pinhão. J. Oliveira (1937). Aleluia, Aveiro. Fotografía: José Luis Mingote Calderón, 2012.

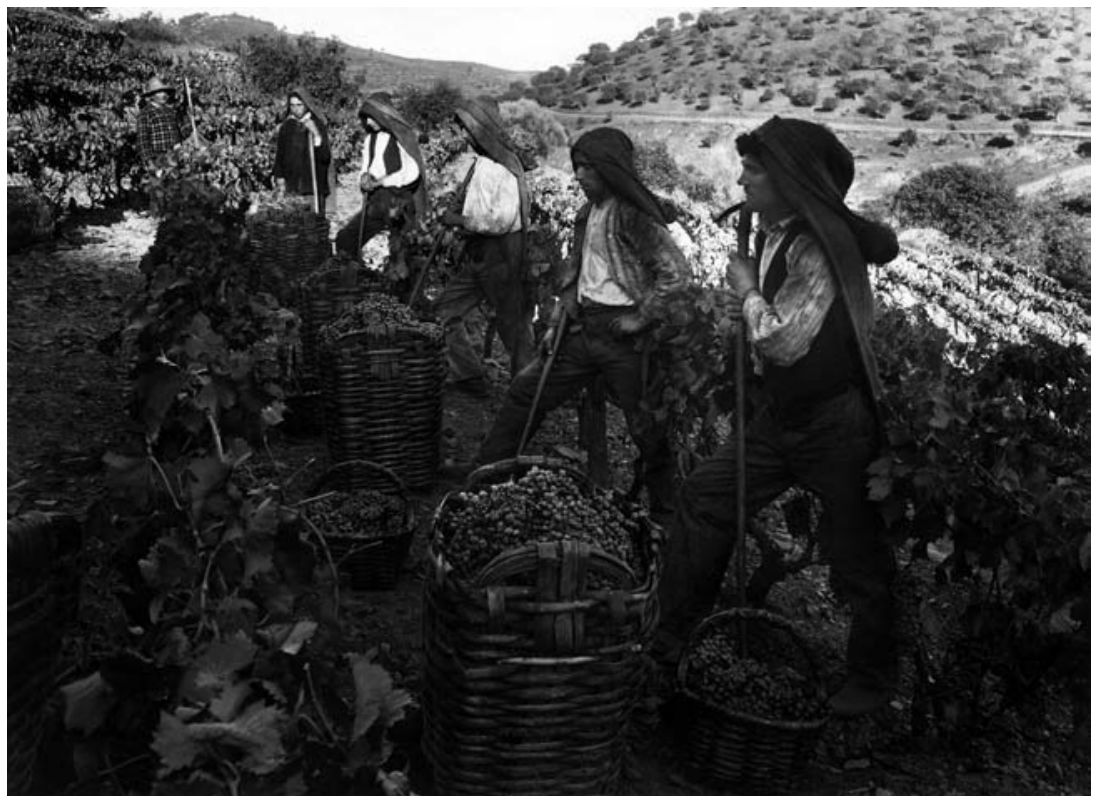

FIgURA 12.-La misma imagen de la figura anterior, en fotografía de Álvaro Cardoso de Azevedo (Casa Alvão). Fotografía del Instituto dos Vinhos do Douro e do Porto. 


\section{LOS CESTOS Y EL CULTIVO DEL OLIVO}

La recogida de la aceituna es otra de las faenas que aparece representada en los paneles de azulejos, si bien en un número bastante menor que la anterior. Como aquélla, muestra una serie de gestos interesantes, así como algunas situaciones que cabe explicar recurriendo a la bibliografía portuguesa sobre cestos o por fotografías de la época con temática similar a lo representado en los azulejos. Las escenas aparecen en estaciones o mercados de la mitad sur de Portugal y, en concreto, en Vila Franca de Xira, Setúbal, Montemor-o-Novo, Fronteira y Cabeço de Vide, y en ellas se ven cestos pequeños con un asa central, de tipología muy generalizada y polifuncionales, junto a otros mayores con dos asas laterales verticales. Un tipo de cestos que M. H. Santos Silva (1961: 81) indica que, en Elvas, se denominan cesta da azeitona y, a la vez, da vindima.

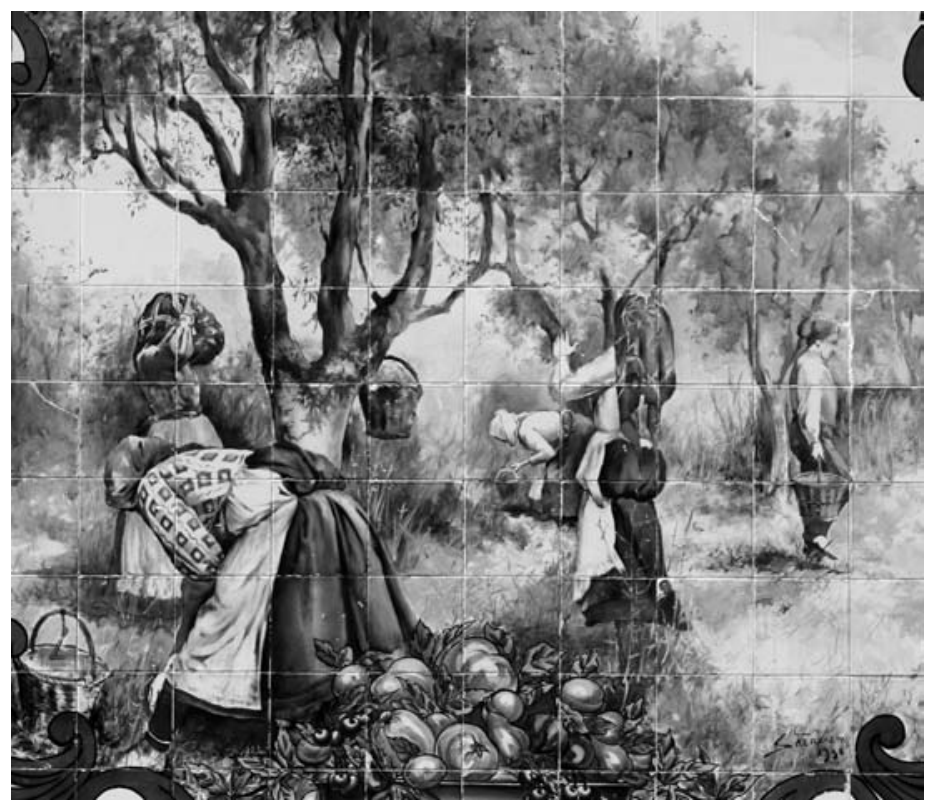

FIgURA 13.-Recogida de la aceituna. Mercado municipal de Vila Franca de Xira. S. a. (S. f., comienzo de los años 30). Posiblemente, Fábrica de Louça, Sacávem. Fotografía: José Luis Mingote Calderón, 2014.

En un panel del Mercado de Vila Franca de Xira (fig. 13), un grupo de mujeres recoge aceituna mediante ordeño, apreciándose un cesto colgado del olivo a través de un gancho, mientras un hombre lleva un pequeño cesto cogido por el asa, similar a los usados por las mujeres. El uso de este tipo de ganchos fue mencionado hace muchos años por E. Ribeiro (1930: 80), al hablar de la cêsta, cesto con un asa central y de uso polivalente que sirve para la siembra, las vendimias etc.; este autor mencionó que era normal que llevara un gancho, generalmente realizado en madera ${ }^{15}$. Tam-

${ }^{15}$ En Felgueiras, hay cestas que se cuelgan de un gancho, para vendimiar en las viñas enforcadas, a las que los vendimiadores llegan subidos en escaleras (Kuoni, 1981: 139), en alu- 
bién, en este mercado aparecen dos mujeres con un cesto similar a los citados para la siembra y vistos en la recogida de la aceituna, en una escena descontextualizada, tras un burro cargado con cajas. Curiosamente, las figuras del panel están sacadas de dos fotografías distintas, ambas de la Ilustração Portuguesa; la de las dos trabajadoras asociadas a la recogida de la aceituna, se encuentra en el número 354 (1912), mientras que la del burro, relacionada con la exportación de frutas, está en el 340 $(1912)^{16}$.

En el mercado de la localidad alentejana de Montemor-o-Novo se dibuja una escena asociada a la recogida de la aceituna, que presenta algunos problemas (fig. 14). En ella, un grupo de mujeres semiarrodilladas parece rebuscar entre ramas de olivo y haber obtenido un pequeño montón de aceituna que aparece junto a las dos de la derecha, una de las cuales muestra un puñado. Junto a ellas, vemos dibujados dos tipos de cestería, mucho más trabajada y decorada una que la otra; característica que transmite la impresión de que nos hallamos ante un cesto cuya función primordial no sería precisamente la de recoger aceituna ${ }^{17}$. Por los pocos frutos presentes, la interpretación de la escena choca con otras que aparecen en fotografías de la época y que muestran la limpieza de las ramas de las aceitunas, tras el vareo. Sin negar que la imagen esté reflejando esa limpieza, el escaso producto recogido parece indicar que quizá la fotografía no sea todo lo real que parece. ¿Habría que relacionarla con una práctica concreta dentro del proceso de recogida de la aceituna, que se denomina revisco en el Alentejo (información obtenida en Vimeiro) y que sería similar al espigueo o a la rebusca que se hace con cereales o uvas en muchas zonas? O, quizá, simplemente es una imagen creada artificialmente que imita la realidad, y que se ve en revistas y libros de la época, como sucede en la Ilustração Portuguesa, que en su número 359 (1913) publica un artículo de F. dos Reis Sousa en el que se habla de la producción mecanizada del aceite, acudiendo a informaciones de la finca de un alargado propietario de la Beira interior, en concreto en Castelo Branco. Una de las imágenes que ilustra "A nossa riqueza agrícola. O fabrico do azeite", se titula "A escolba da folha diante do guarda" (fig. 15) ${ }^{18}$.

sión a las viñas armadas en árboles como las vistas asociadas al Miño, y que ya he citado, en Oporto y Leça do Balio. También, para los cestos globulares que se colgaban de la escalera, en este tipo de vendimia, se recurría a los ganchos en Peñafiel, que en algún caso son ganchos modernizados, de metal, como lo documenta T. Soeiro (2008-2009: 260, 263 y fig. 6, 2); en el texto, el número citado alude a un cesto de siembra, si bien la presencia del gancho hace pensar en que el pie de la ilustración es el correcto. Por otro lado, el cesto de siembra, que aparece en la fig. 6, 3, presenta semejanzas con el de vendimia, aunque es menos hondo.

${ }^{16}$ Sobre esta revista, de la que se copiaron muchas de sus fotografías, se puede consultar el libro de F. Costa y M. C. Serén (2004).

${ }^{17}$ Ambos tipos de cestos se vendían en la ciudad, en 2012.

${ }^{18}$ La imagen reproduce los trabajos en la finca de António Cezar d'Abrunhosa (1881-1941), propietario y fotógrafo aficionado que ha dejado un amplio conjunto de imágenes de contenido agrario. Hay publicados tres libros sobre su obra, dedicados respectivamente al olivo, la viña y el cereal (D'Abrunhosa e Mansinho 2003; D'Abrunhosa e Mansinho y Delgado 2005; y D'Abrunhosa e Mansinho y Azevedo 2012), en los que se fechan las imágenes en los años 20 y 30, pero como se ve algunas cabe datarlas ya a comienzos de los años 10 . 


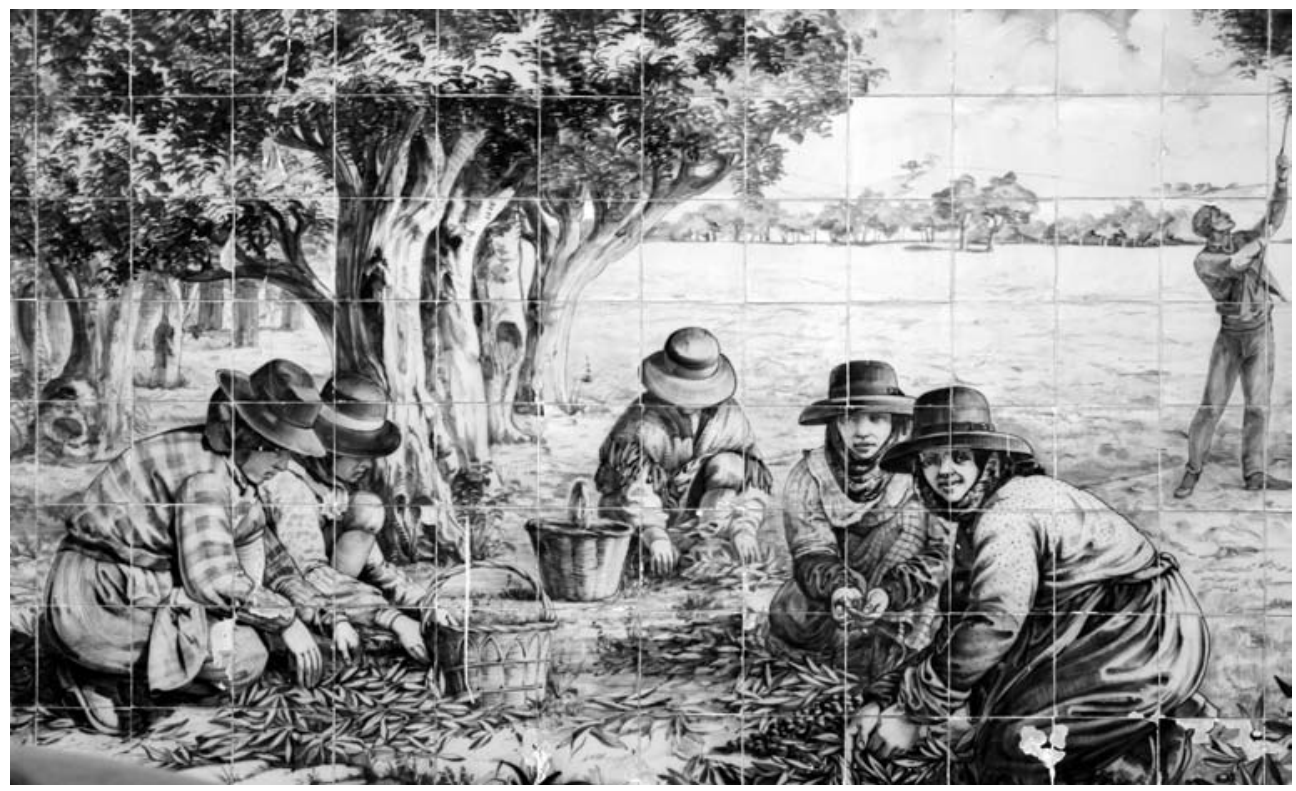

FIGURA 14.-Mujeres limpiando aceituna. Mercado municipal de Montemor-o-Novo. G. Q. (S. f.). Fábrica Sant'Anna, Lisboa. Fotografía: José Luis Mingote Calderón, 2012.

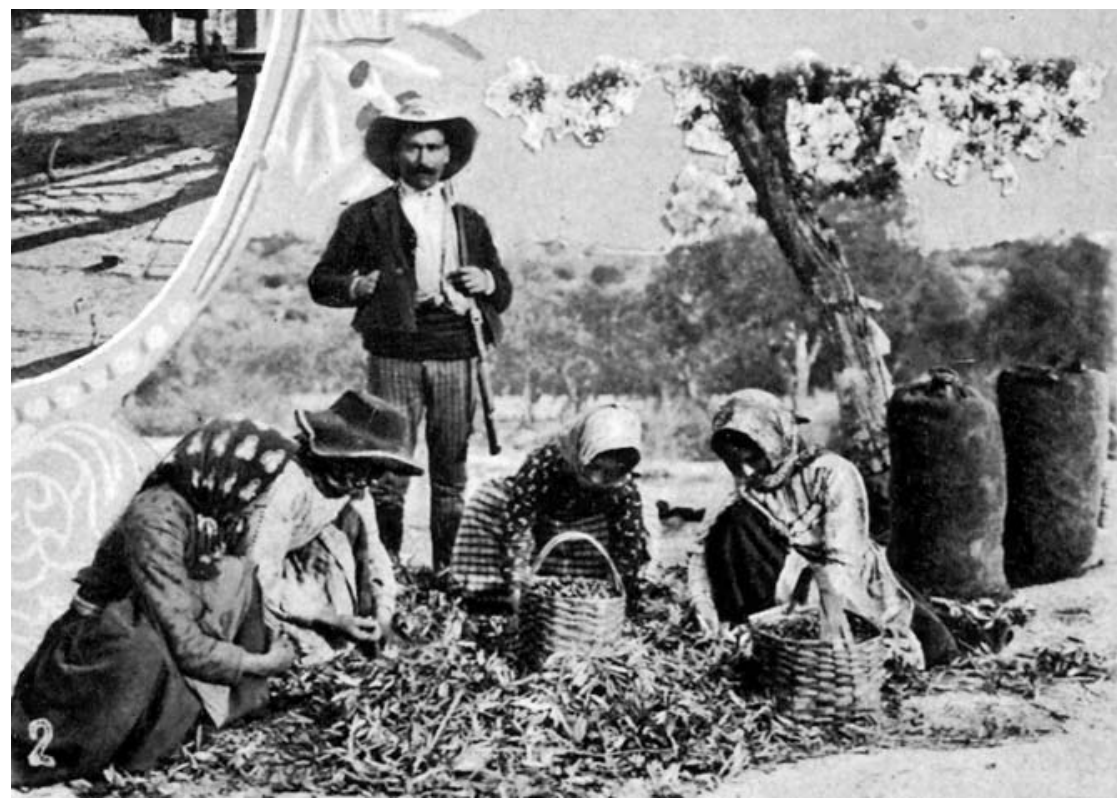

FIGURA 15.- "A escolha da folha diante do guarda", en una explotación de Castelo Branco. Ilustração Portuguesa 359 (1913). Fotografía de António Abrunhosa. 
También, años más tarde, en Le Portugal et son activité économique (VV. AA. 1932: 195-196) se describe y critica la recogida de aceituna mediante vareo, ya que produce la rotura de muchas ramas y obliga a la limpieza y selección de las aceitunas; el texto se ilustra con una escena similar, calificada como de limpieza de la aceituna (fig. 16).

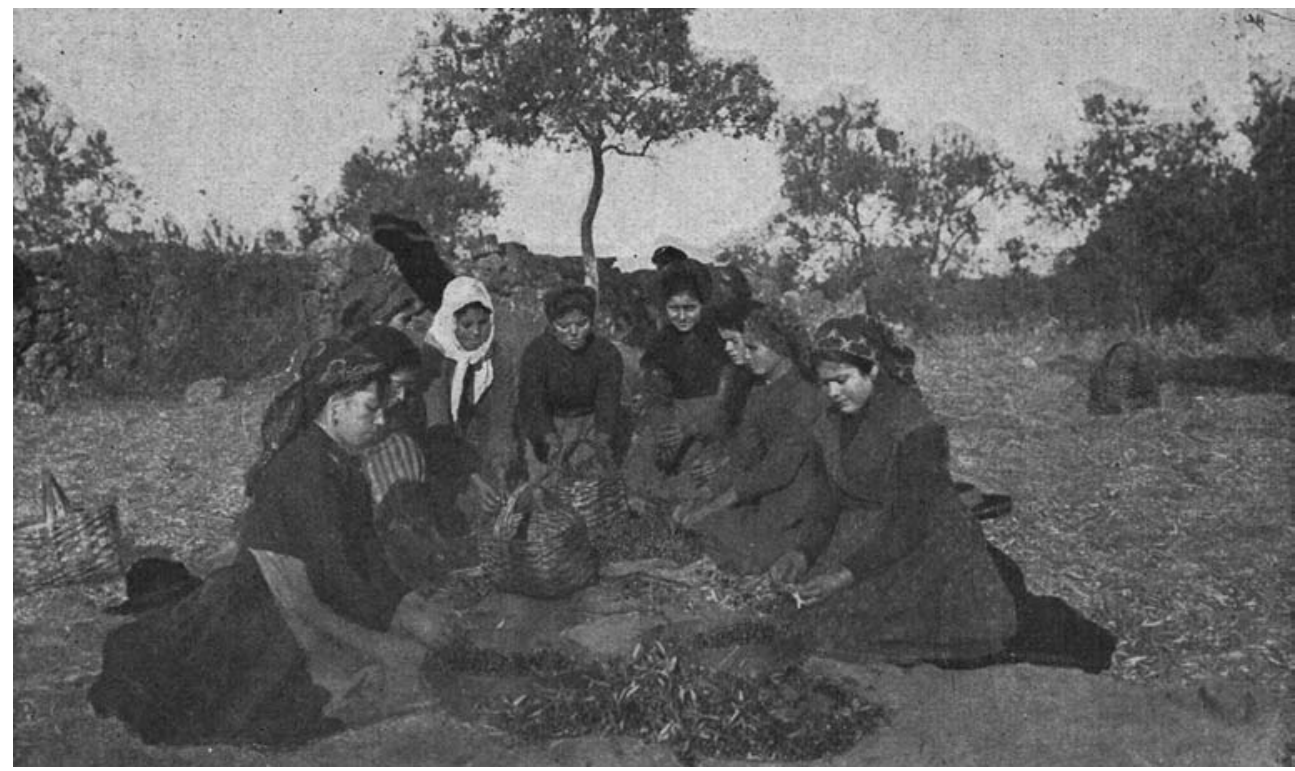

FIGURA 16.— "Nettoyage des olives", Le Portugal et son activité économique (VV. AA. 1932: 196).

No se puede negar que la escena de Cabeço de Vide (fig. 17) sea una simple recogida de aceituna, en la que además de los pequeños cestos donde se va reuniendo la aceituna, hallamos un recipiente mayor, de mimbre y con dos asas, que es cogido por una mujer y que cabe identificar como el citado cabanejo - que carga y descarga un hombre especializado, el cabanejeiro-, a pesar se ser algo más alto que el citado por E. Ribeiro. Pero, quizá haya que pensar que lo que se nos muestra esté en relación con la costumbre que relata este autor, quien indicó que, en el Alentejo, tras la vendimia, detrás de las mujeres que hacen estos trabajos, van los niños con una pequeña cesta a recoger los racimos olvidados por sus madres, para ayudarlas (Ribeiro 1930: 44-45). A pesar de que no diga explícitamente que esta especie de rebusca se hiciera tras la recogida de la aceituna, cabe pensar que pudiera ser lo mismo, ya que refiere esta información tras aludir al cabanejo como cesto para ambas tareas. De ser así, y con todas las dudas, las imágenes de Montemor-o-Novo y Cabeço de Vide, podrían reflejar costumbres de gente pobre trabajando en grandes propiedades, como lo eran los campesinos asalariados alentejanos, constatándose la presencia del capataz que observa la acción en Cabeço de Vide.

En el Mercado do Livramento de Setúbal se encuentra una escena de limpieza de la aceituna mediante el aventado con una criba de materias vegetales, y en la que se ve un cesto grande, troncocónico, situado en el suelo; muy similar al usado en el resto del Alentejo (fig. 18). 


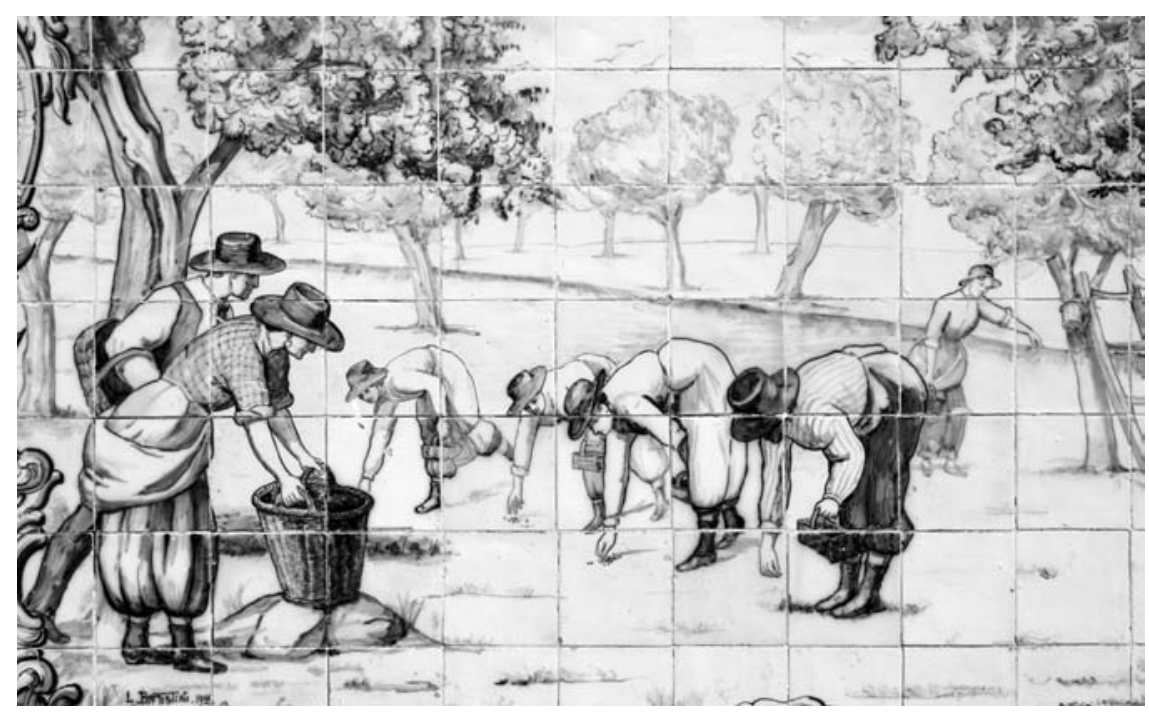

FIgURA 17.-Recogida de la aceituna. Estación de Cabeço de Vide. Leopoldo Battistini (1933). Fábrica Constância, Lisboa. Fotografía: José Luis Mingote Calderón, 2012.

FIGURA 18.— "Colheita da azeitona". Mercado do Livramento, Setúbal. Pedro Pinto (1930). Fábrica Arcolena, Lisboa. Fotografía: José Luis Mingote Calderón, 2014

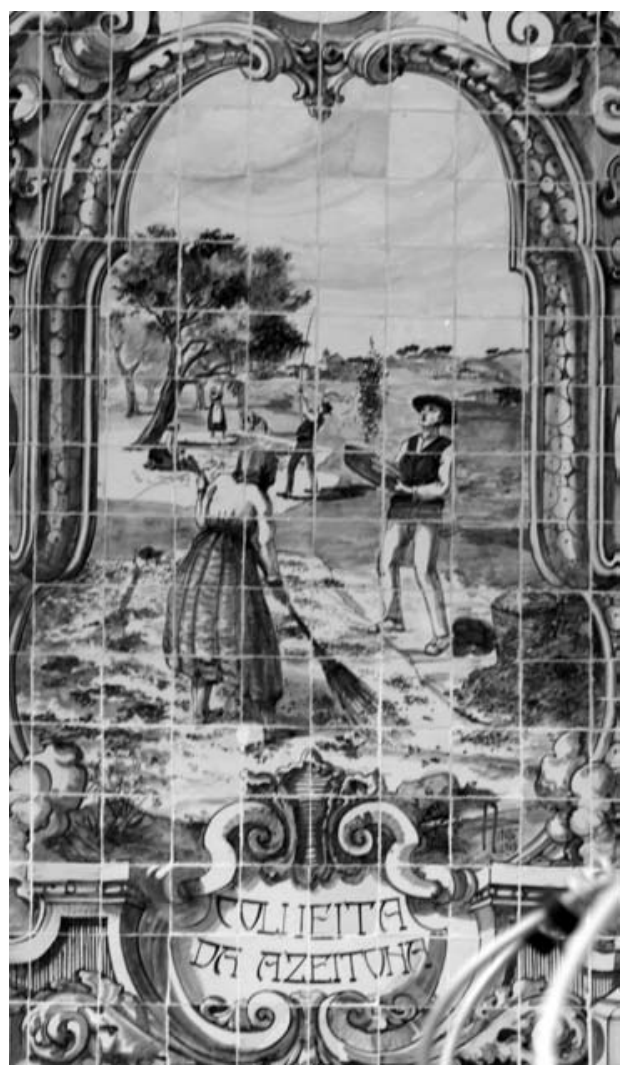

Revista de Dialectología y Tradiciones Populares, vol. LXIX, n. 2, pp. 435-466, julio-diciembre 2014, ISSN: 0034-7981, eISSN: 1988-8457, doi: 10.3989/rdtp.2014.02.009 
En la estación de Vila Franca de Xira, hay una escena a priori un tanto extraña, en la que vemos varios cestos de mimbre de diferentes tipos en el suelo, y a un grupo de mujeres sentadas, con unas bandejas del mismo material sobre sus piernas (fig. 19). La explicación de lo que están haciendo se encuentra, una vez más, en la revista Ilustração Portuguesa. En el artículo ya citado sobre el aceite, aparecido en el no 359 (1913), F. dos Reis Sousa comenta que un tercio de la producción de aceituna de la zona va destinada "para a praça", en referencia a su venta en el mercado. Y este destino hace necesario que sean seleccionadas, lo que se ilustra con una imagen que sirvió para la estación citada, si bien ha sufrido la alteración de incluir en primer plano a dos personas conversando que, en origen, proceden de dos fotografía diferentes de la misma revista (fig. 20).

FIGURA 19.-Mujeres seleccionando aceituna. Estación de Vila Franca de Xira. J. Colaço (1930). Fábrica Lusitânia, Lisboa. Fotografía: José Luis Mingote Calderón, 2012.
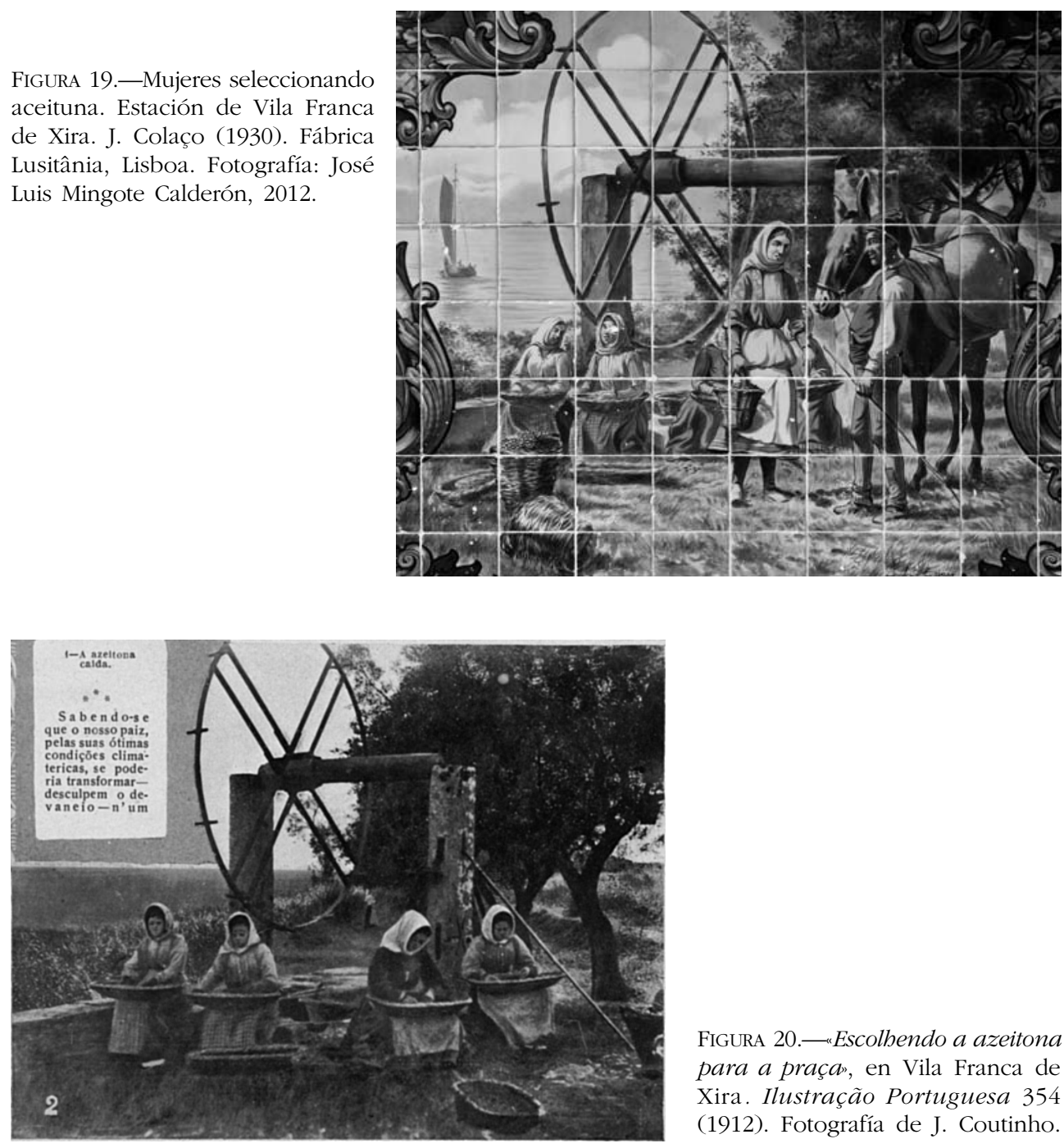

FIGURA 20.—Escolhendo a azeitona para a praça, en Vila Franca de Xira. Ilustração Portuguesa 354 (1912). Fotografía de J. Coutinho. 


\section{LOS Cestos En los Cultivos asociados a los CeREAles}

Los trabajos relativos al cultivo de los cereales, vinculados a cestos, están muy poco representados en los azulejos, ya que he documentado sólo la siembra y el descamisado del maíz. El primero se encuentra en el Mercado do Livramento de Setúbal, mientras que el desgrane aparece en los bancos del Parque da República, en Lamego y en el mercado de Santarém.

En Setúbal, los cestos son los característicos troncocónicos con asa central, pequeños y hechos en mimbre o una fibra similar. La composición muestra tanto a hombres como a mujeres detrás de una vertedera (restaurada en 1991), sembrando a chorrillo en el surco abierto por esta. Mientras que dos hombres se inclinan hacia el suelo, la mujer camina erguida detrás de ellos. A pesar del título del panel, Lavra e sementeira, que parece remitir a cereales, quizá se pudiera pensar en una siembra de patatas, aunque los cestos de siembra documentados por la investigación responden a este tipo de asa central (fig. 21) ${ }^{19}$.

En la segunda escena, en Lamego, encontramos cestos similares a los empleados en la vendimia en la zona, es decir, los cestos viñateros del Duero ${ }^{20}$. En ella, Jorge Colaço ha elegido un momento festivo como hizo repetidamente en otros casos al representar romerías o ferias. Aquí ha optado por el descamisado del maíz, en el que mozos y mozas trabajan y se divierten, sobre todo ante el hallazgo del milho rei, o mazorca con granos rojos (Fig. 22). Como ilustración y complemento de esta imagen, se puede citar un texto coetáneo, de G. Felgueiras (1932: 49), quien narra estos actos con una buena dosis de carga poética: "Após a colbeita [el maíz] é conducido para as eiras para ser "descamisado" entre risadas e cantorías, sendo as "desfolhadas" pretexto para serões de estrondeante alegria" en las que "colaboram campónios faceiros e espadaüdos e cortejadas moças", y añade: "São scenas típicas das desfolhadas os desafios, os alegres folgares e a conquista do milho rei, espiga de grãos vermelhos que dá, a quem encontra, o direito a distribuir abraços por todos os circunstantes".

La escena de Santarém, que representa a varias mujeres situadas sobre el suelo, al aire libre, y con cestos a su lado, pudiera plantear ciertas dudas sobre su contenido. Dudas que desaparecen al encontrar el original que sirve de ilustración al libro Ribatejo histórico e monumental, de F. Cancio (1938: 73), cuyo pie de foto aclara totalmente lo dibujado al indicar que se ha fotografiado una "Escamisada do milho" y que en el Ribatejo este trabajo no tiene la animación existente en el Miño, aunque en él se generan amores similares, al compás de las canciones. Además, se menciona el nombre del autor de la fotografía: José Osorio.

${ }^{19}$ La pared donde estaban los azulejos se desplomó en febrero de 2012, y en mayo de 2103 ya había sido reconstruida. En el norte, la cestería de madera rajada presenta "cestas para vindimas, frutas, sementes, etc." que son de paredes altas que se cierran algo en la boca y tienen el asa en arco, aunque las medidas cambian de cestero a cestero. De Braga hacia el norte, las cestas para vendimia y recogida de frutos, que muchas veces sirven también para siembra, son pequeños cestos altos de curvatura variada, casi siempre redondos, y las hechas especialmente para siembras presentan un asa central (Galhano 1961-1962: 265-266, 268 y dib. 7).

${ }_{20}$ M. H. Santos Silva (1961: 71) indicaba que en la Beira Baixa, el poceiro de Sertã -nombre con el que se designan los cestos de vendimia de nuestra figura 7 e iguales a estos de Lamegose usaba con uvas y también para otras faenas agrícolas, como el transporte de estiércol. 


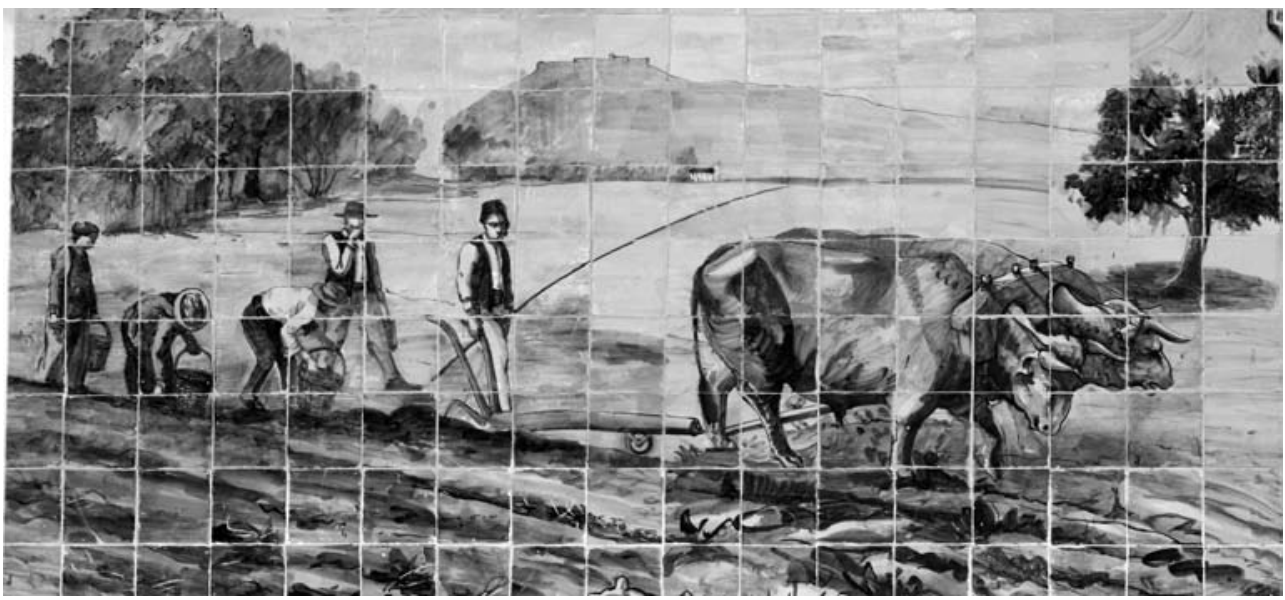

FigurA 21.— "Lavra e sementeira". Mercado do Livramento de Setúbal. Pedro Pinto (1929 o 1930). Fábrica Arcolena, Lisboa. Fotografía: José Luis Mingote Calderón, 2014.

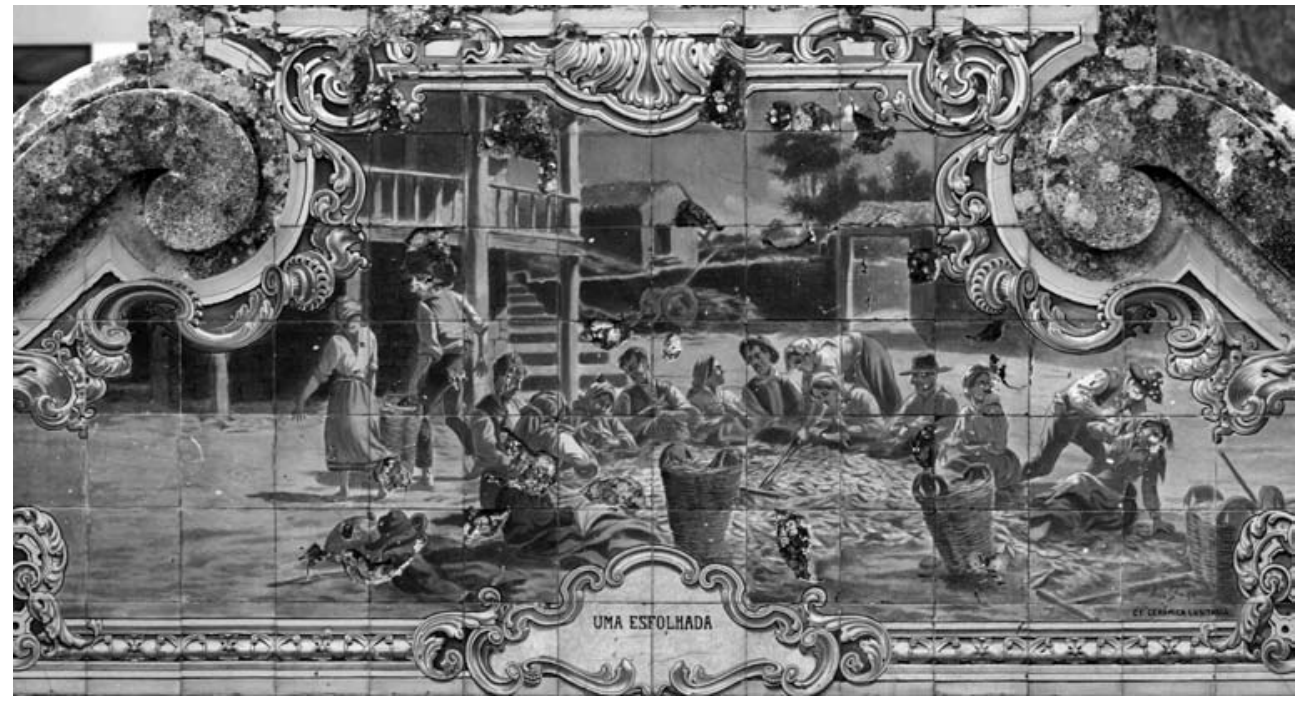

Figura 22._ "Uma Esfolhada”. Banco en el Parque da República, de Lamego. Jorge Colaço (1932). Cerámica Lusitana, Lisboa. Fotografía: José Luis Mingote Calderón, 2013.

\section{TRABajos aSOCIADOS A LA RECOGIDA DE ALGAS}

Hay tres paneles que nos muestran un trabajo interesante, y muy localizado geográficamente, como es la recogida de algas para su utilización como abono agrícola ${ }^{21}$.

${ }^{21}$ Sobre el uso de las algas, para ser usadas como fertilizantes, es imprescindible la consulta del trabajo de E. Veiga de Oliveira et alt. (1975). 
Junto a la ya citada de Aveiro, encontramos este tema en otro panel de esta estación y en la estación de Caminha. Además de la mencionada escena copiada de una postal, en la que veíamos cestos sobre las barcas, aparece otra en la que dos mujeres conversan con un hombre subido en un carro, mientras que tras ellas hay un montón de algas. Una de ellas agarra un cesto vacío, cogido por un asa de cuerda (fig. 23).

En los años 30, en la estación de Caminha se muestra la llegada de las algas al muelle, en donde se ve un cesto a medio levantar y por tanto tampoco hay gestos de trabajo asociados a los recipientes (fig. 24). Es una actividad que es posible observar actualmente, ya que aún se recogen algas en Moledo, en el mismo concelho, que seguramente sería el lugar de origen de la barca atracada en el muelle y cuya playa también se representa en los azulejos de esta estación. El original procede del famoso fotógrafo portugués Joshua Benoliel, que había retratado varias escenas de esa localidad en 1911, en una de las ocasiones en que documenta las incursiones militares de Paiva Couceiro, que desde Galicia tienen lugar contra la recién instaurada República, y que se publican en el número 280 de la Ilustração portuguesa ${ }^{22}$. En ese momento, la revista titula la foto incorrectamente, aludiendo al alimento para el ganado: "desembarque do pasto para o gado nas margens do Minho", lo que será corregido al indicar "Caminha. Desembarque do sargaço", en la portada del no 365, en 1913, en la que se reproduce parcialmente la misma imagen, recortándola.

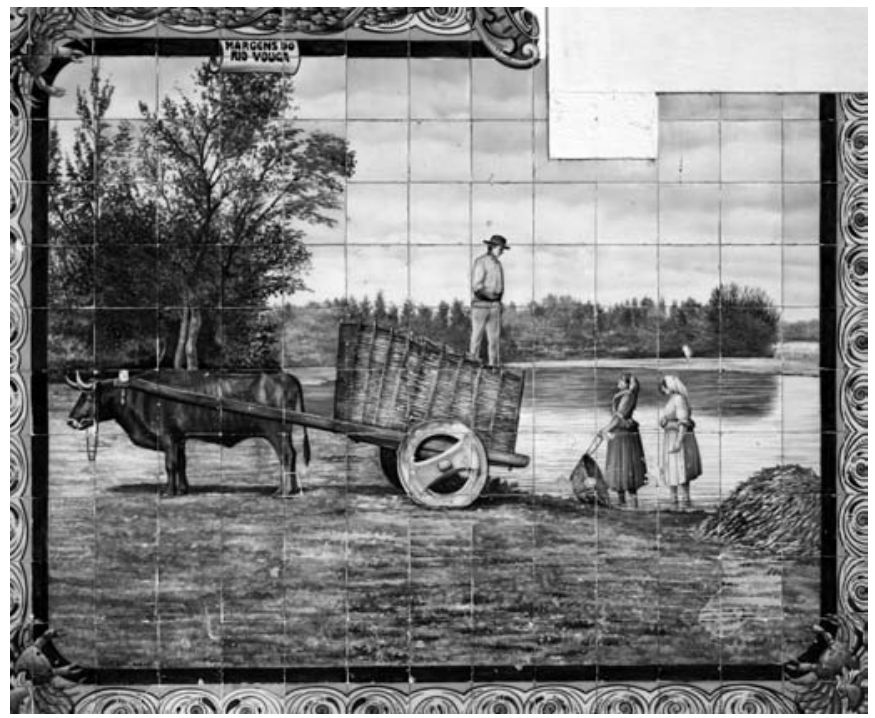

Figura 23.— "Margens do Río Vouga". Recogida de algas. Estación de Aveiro. F. Pereira (1916). Fonte Nova, Aveiro. Fotografía: José Luis Mingote Calderón, 2008.

${ }^{22}$ En el artículo — "No paiz dos conspiradores", en pp. 7-21- se contrapone la situación de los exilados monárquicos en Galicia con la situación de los marineros portugueses, "nas margens pittorescas e idylicas de Minho formoso" confraternizando sentimentalmente con las mozas y labradoras locales, a las que droutinaban de ideología republicana. Otra de las fotografías del artículo, unos carreteros transportando troncos de pinos desde Melgaço a S. Gregorio, se reproduce también en la estación de Caminha. 


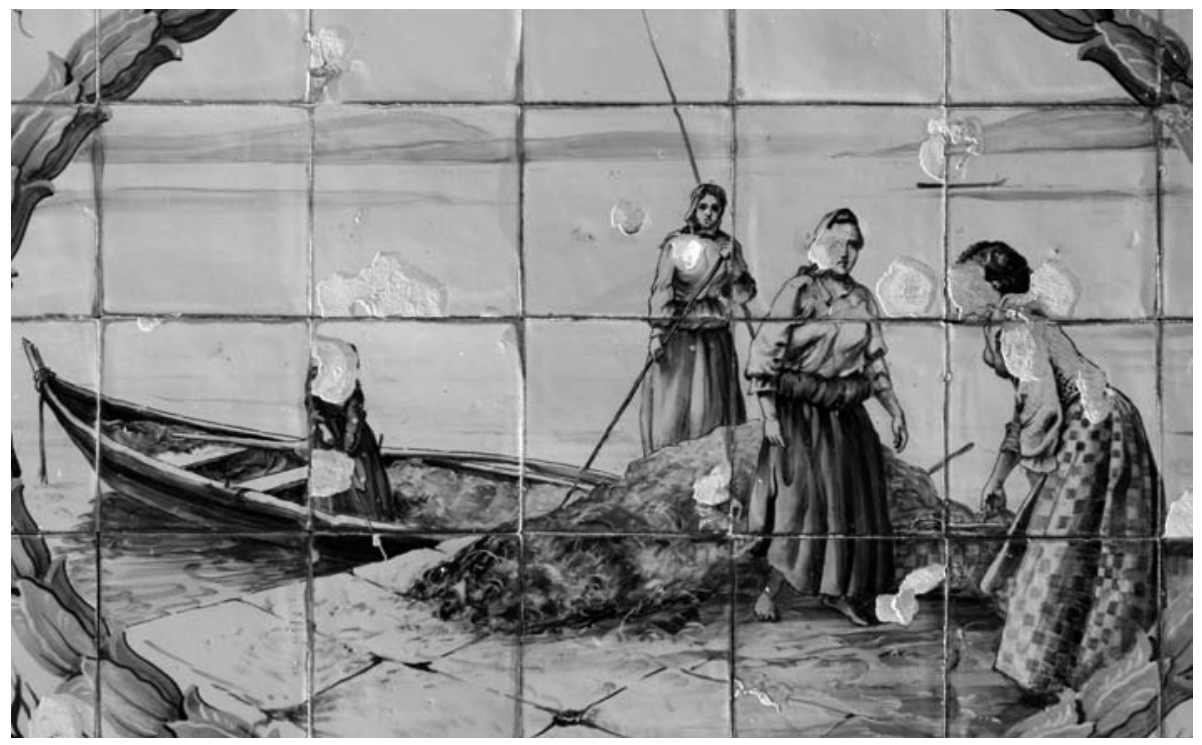

FiguRA 24.-Descarga del sargazo. Estación de Caminha. Gilberto Renda (S. f., años 30), Fábrica Sant'Anna, Lisboa. Fotografía: José Luis Mingote Calderón, 2012.

\section{CESTOS EN ESCENAS VARIADAS}

Para finalizar con los contextos de trabajo en que los cestos están presentes, voy a aludir a los que aparecen en una variada gama de situaciones, comenzando por aquellas que tienen una cierta relación con la agricultura. En los vestíbulos del mercado de Setúbal se representa a una mujer andando por un camino y llevando un cesto plano y sin asas, aparentemente, sobre la cabeza. A pesar de que la forma de representar el fruto que carga no sea muy precisa, cabe pensar que seguramente sean naranjas, dado que se trata de un importante producto local.

Otras escenas nos muestran la venta de productos en los mercados por parte de personas que en alguna ocasión, aunque no siempre, cabría identificar como campesinos. Se trata de mercados al aire libre que se representan sólo por las personas y los elementos que allí se venden, o bien que incluyen alguna estructura de madera. Conviene recordar que a este tipo de lugares acudían personas de los alrededores y, a veces, de lugares más alejados, según la importancia del mercado. Un hecho que puede modificar la representatividad localista de las imágenes. En ocasiones, los cestos aparecen transportados por las personas, que mayoritariamente son mujeres y, por tanto, lo hacen sobre la cabeza, aunque, en muchos casos, se encuentran en el suelo, como sucede en los mercados de Setúbal y Santarém, o en la Praça da República, en Viseu (fig. 25), y el Parque da República, en Lamego. Pueden estar llenos de una variada gama de productos que, normalmente son frutas, si bien también se representa un cesto de compra, como la condessa ${ }^{23}$, que aparece en Setúbal; también hay

${ }^{23}$ Según F. Galhano (1961-1962: 326-327), la condessa se daba en la línea férrea del Duero y, en el momento en que escribe, se fabricaba en Marco de Canaveses desde hacía unos 25 años y 
otros que se encuentran tapados por un paño y que podrían contener panes, como ocurre en Viseu.

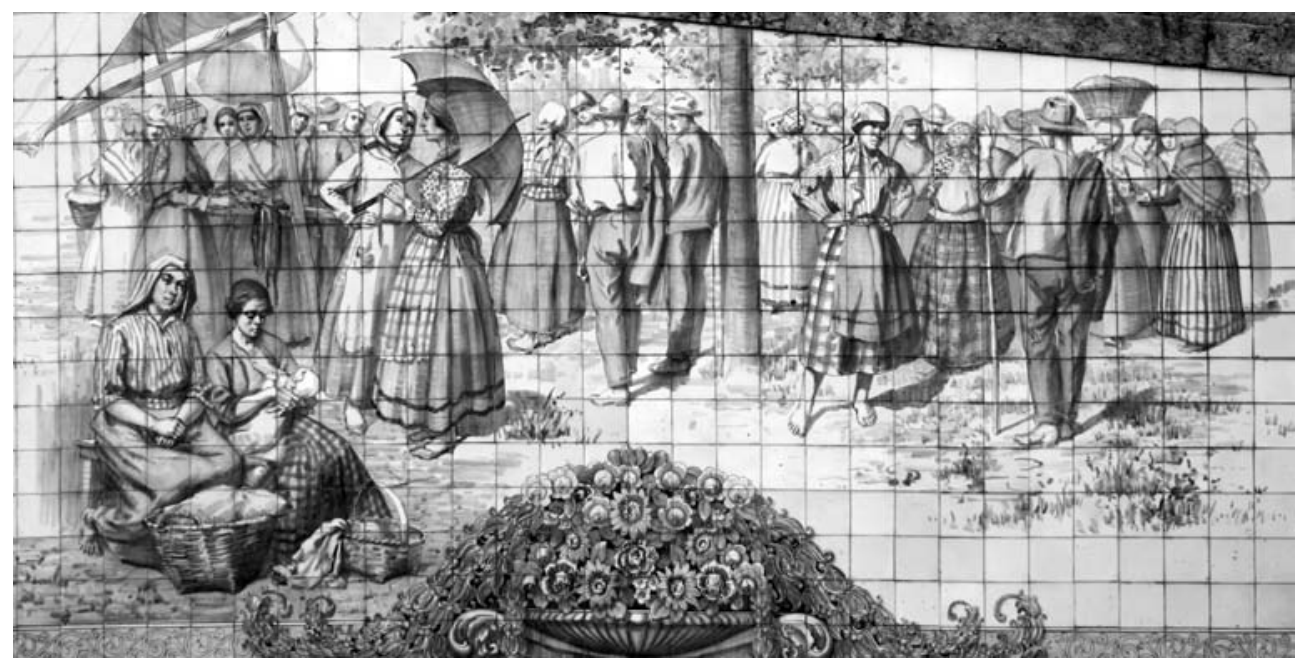

Figura 25.-Escena de feria y mercado. Praça da República, en Viseu. Joaquim Lopes (1931). Fábrica do Agueiro, Vila Nova de Gaia. Fotografía: José Luis Mingote Calderón, 2013.

En Santarém, en otra escena de mercado, aparece un cesto caído que muestra la paja que se está comiendo un burro, mientras que al fondo se ve un cesto como los de vendimia para transportar en caballerías que estudió F. Galhano (1966). En la estación de Caminha vemos una mujer con un cesto a la cabeza, tapado por un paño, por lo que cabe pensar en que lleva panes, en la plaza en lo que parece ser un día de mercado.

Finalmente, hay un panel que no muestra un trabajo agrícola, a pesar de que podría pensarse lo contrario. También en la estación de Caminha, vemos a varias mujeres en una era rodeada de hórreos, uno de los cuales tiene la puerta abierta, en donde aparecen manojos de una materia poco detallada gráficamente; junto a ellos, se dibuja un cesto casi globular de mediano tamaño, situado en el suelo tras uno de los fajos (fig. 26). A primera vista, no queda muy claro qué están haciendo estas mujeres, pero la solución se encuentra, una vez más, en fotografías anteriores. En concreto, esta imagen apareció reproducida en uno de los folletos publicados con motivo de la Exposición Iberoamericana de Sevilla de 1929 —Portugal. Entre-Douro-e-Minhosin que su pie de foto o el texto aludan a ningún trabajo en concreto, ya que se la titula como Uma eira minhota, y en el texto del librito solo hay una breve referencia genérica al lino, sin mencionar las eras. Esa es precisamente la clave, ya que el pa-

se denominan con números, según el tamaño. Este cesto que tiene una sola tapa, combada, y un asa longitudinal, como se ve, aparecía ya en 1930 en otros lugares bastante alejados del citado río. M. H. Santos Silva (1961: 100-101) indica que pocos cestos de compra se restringen a una región determinada y que sus nombres varían muchísimo. 
nel reproduce una imagen de D. Alvão que pertenece a una serie de la que hay reproducciones en varios soportes, como revistas y postales, y que se expusieron públicamente en 1914. La serie, como se deduce de otra imagen procedente de una postal, está tomada en Nine, a $50 \mathrm{~km}$. al suroeste de Braga y en la misma línea férrea que esta estación, e ilustra el assoalhamento del lino, su blanqueado al sol. No obstante, no es muy equivocado pensar que los problemas de interpretación que pueden surgir ahora con este panel no existieran en el momento en que fue realizado. El motivo es muy claro: en la región miñota, el lino y la lana eran algo característico, que producían una actividad incansable para la mujer, la cual, en palabras de Ramalho Ortigão: "fia, tece, carda, espadela, borda e maneja os bilros" (citado por Ribeiro, s.f., [1911]: 53, tomado de As (arpas) ${ }^{24}$.

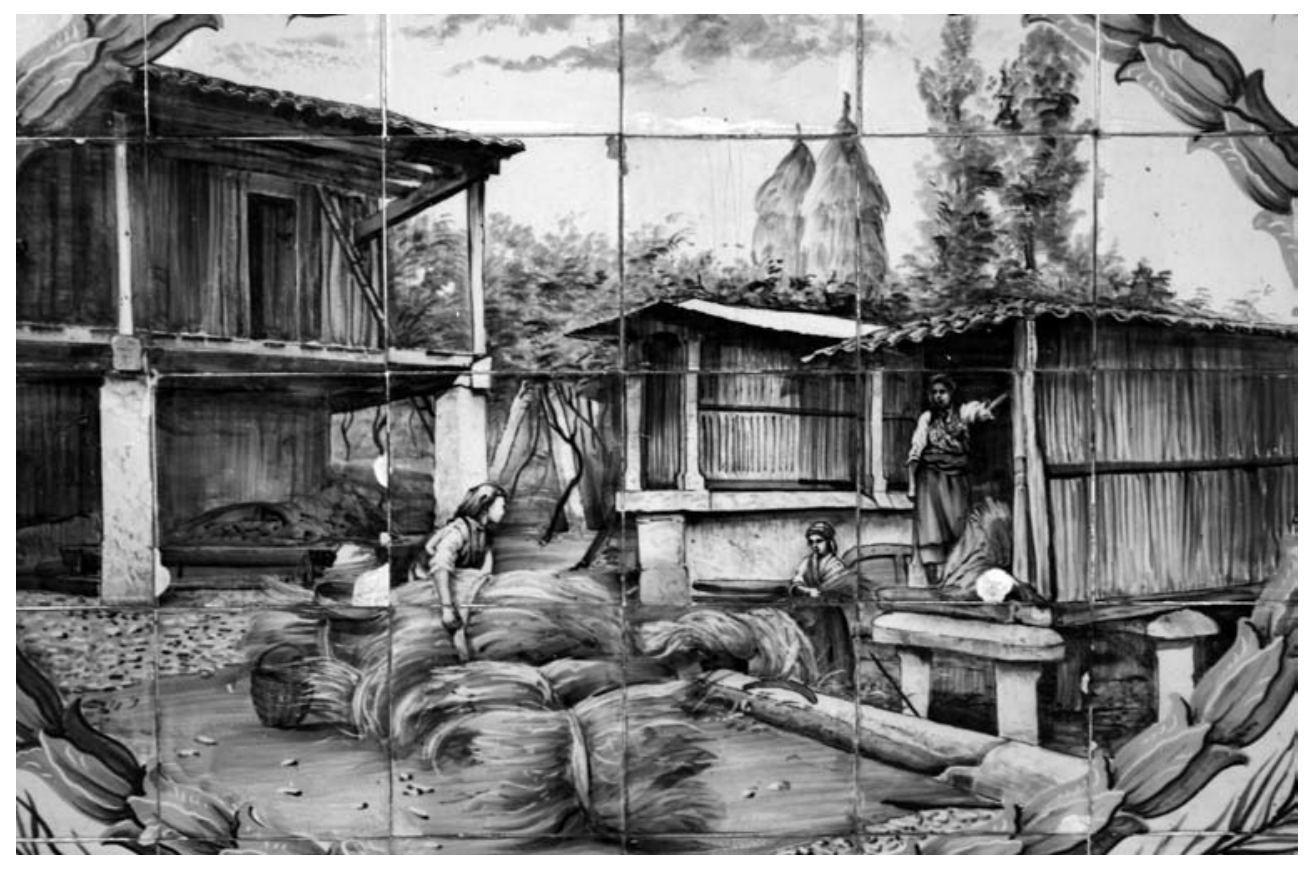

Figura 26.-Blanqueado del lino al sol. Estación de Caminha. Gilberto Renda (S. f., años 30). Fábrica Sant’Anna, Lisboa. Fotografía: José Luis Mingote Calderón, 2012.

Fuera del contexto de trabajo agrario, pero asociado a campesinos, es posible documentar a uno cocinando en el campo, en el Mercado de Santarém; o una esce-

${ }^{24}$ Estos trabajos aparecen también en postales de principios de siglo (Vicente de Sousa y Neto Jacob 1985: 142-145) y habían merecido la atención, en 1903, de un artículo de B. D. Coelho en Portugalia, sobre la "Industria caseira de fiação, tecelagem e tingidura de substancias textis no districto de Viana do Castelon. O, en otro contexto, un artículo posterior, editado en el número 398 (1913), pp. 387-391, de la Ilustração Portuguesa, "O linho", centrado en esta provincia; en él, se comenta que la industria de tejidos de lino es la más próspera de su zona sur y que ha generado muchas fábricas. Por otro lado, califica de "pitoresco cuidado agrícola" a su proceso de trabajo, del que no menciona la fase ilustrada en Caminha. 
na en la que aparece un cesto con comida en el ámbito de la era, en Beja, donde también hay una mujer con un bolso bajo el brazo, que parece hecho de esparto ${ }^{25}$. En una tienda de esa ciudad aparece otra escena de siega donde se dibuja un cesto similar, en el que se aprecia una botella sobre un paño que tapa la comida.

A ello hay que añadir un cesto situado junto a una pareja en la que la mujer lleva una hoz, en la estación de Miranda-Duas Igrejas; lo llamativo es que ese cesto - típico de llevar comida o de recogida de frutos- no aparece en la foto original realizada por E. Biel (1902-1908: vol. I) y que localiza en Miranda do Douro ${ }^{26}$. Un cesto similar se ve colgado de una valla, junto a dos mujeres, en la estación de Leça do Balio, sin que se pueda decir más sobre el contenido de la imagen.

Unos serones, posiblemente de esparto, aparecen en una escena de transporte de panes junto al acueducto de Elvas, en la estación de esa localidad. Los serones se colocan sobre un burro. También sobre un burro van unos cestos dobles, aparentemente de mimbre, en una escena del Mercado de Santarém, copiada de una fotografía, en la que se documentan unos fazendeiros (uno de los cuales ha desaparecido en el azulejo) atravesando una zona de agua.

\section{LAS FORMAS DE LLEVAR LAS CARGAS}

Además de las referencias que he ido mencionando a lo largo del texto, creo pertinente añadir ahora algunos datos sobre la manera de llevar las cargas y, por lo tanto, los cestos, que han sido recogidas por diversos autores. Al hablar de las primeras, A.-G. Haudricourt (2010: 65-76, en especial 67-73) hizo una interesante referencia a formas de transportar "activas" y "pasivas", según se haga esfuerzo corporal o no. Además, anotó una vía intermedia entre activo y pasivo al referirse al uso del cuerpo ayudado por un brazo. Se podría decir que el transporte femenino sobre la cabeza remite a una relativa pasividad, mientras que el resto de las formas son activas, en mayor o menor medida, ya que producen una mayor tensión muscular, sea en la cabeza, los hombros o los brazos. Como señala este autor, ni los tipos de cargas, ni las formas de llevarlas, están separadas de prácticas de género; el transporte sobre la cabeza, con el uso de rodetes, es universal y casi exclusivamente femenino, frente al transporte sobre el hombro, que es masculino; el llevar un peso a la espalda sirviéndose de una correa que se pasa por la frente es, también, universal y, este caso, tanto masculino como femenino.

B. Kuoni (1981: 299) ya anotó que, en muchas culturas, las mujeres llevan cargas en la cabeza y apoyadas en la cadera, mientras que los hombres, lo hacen encima de los hombros y a la espalda. La forma masculina es de distancias cortas, ya que para las largas se ayuda de un palo o de una cinta, mientras que las mujeres recorren largas distancias con el peso en la cabeza, amortiguado por un rodete y con la particularidad de que los cestos suelen tener forma de bandeja o ser más bajos; asimismo, las cargas a la espalda tienden a concentrar el peso lo más arriba posible, y

\footnotetext{
${ }^{25}$ M. H. Santos Silva (1961: 82) menciona la alcofa, un cesto de esparto, palma o pita, utilizado en zonas del Alentejo para llevar la comida a los trabajadores en la siembra y en otras faenas.

${ }^{26}$ Sobre este fotógrafo se puede consultar el trabajo de P. A. Ribeiro Baptista (2010).
} 
de ahí los cestos con forma de pera invertida, como los de vendimia gallegos y del Alto Duero (Kuoni 1981: 140). Esta autora insistía en esta misma diferencia, cuando decía que de Oporto a Coímbra, aproximadamente, y hasta Viseu y Castelo Branco, predomina la canastra (tipo espuerta) asociada al transporte femenino en la cadera o en la cabeza, mientras que, en esta misma región, los cestos de madera rajada o mimbre eran llevados, en el hombro, por los hombres.

La distinción entre llevar cargas sobre el hombro o la cabeza-cuello-espalda frente a hacerlo sobre la cabeza, en tanto que masculinos y femeninos, respectivamente, también encaja con lo que estudió J. Dias (1993a y 1993b) en Portugal, en dos trabajos de 1971. Este autor señaló la existencia de una diferenciación generalizada en las maneras de llevar las cargas de los hombres respecto a las mujeres, que debía sumarse a la incidencia del tipo de carga y la forma de transporte. Mientras que la mujer prefería llevar las cargas pesadas sobre la cabeza, el hombre lo hacía sobre los hombros o en la espalda. Se trataba de una realidad basada en la costumbre, social e interiormente asumida: el llevar las cargas sobre la cabeza "Isso é só para mulheres", como le decía un informante masculino. Los casos anómalos existían, pero eran escasos y eran, precisamente, eso: la excepción que confirma la regla. Es lo que ocurre con cestos vinculados a actividades marítimas, como la descarga de pescado o su venta en Sines (Dias 1993a: 377), y que también vemos en los azulejos del mercado municipal de Setúbal, donde los pescadores los llevan sobre la cabeza. Esta realidad gráfica puede tener una explicación local relacionada con la que mencionó el investigador portugués: o bien se representó una escena de aquel puerto, o bien la costumbre se extendía algo más al norte, ya que según Dias los pescadores de aquella localidad eran los únicos hombres, en Portugal, que transportaban el producto de la pesca así, en cajas de madera, desde las barcas a la costa, utilizando un sombrero de zinc que los protegía del agua que chorreaba ${ }^{27}$. De estas dos posibilidades, me inclino por la segunda opción ya que, además del panel, se recoge esta forma de llevar los cestos en postales de fechas posteriores.

También, T. Soeiro (2008-2009: 260, 262 y 263), analizando la realidad de Penafiel, comenta que el gigão (cesto para hoja), el cesto da terra (para transportar la tierra en el propio campo, de un lado a otro en función de la pendiente) y el gigo (para llevar uva, espigas o maíz) se transportaban sobre la cabeza, si lo hacía una mujer, o sobre el hombro, si lo hacía un hombre. Frente a esto, el abono nunca se cargaba sobre la persona, sino que el cesto se llevaba bajo y delante de las piernas. Además, indica que los açafates (el término se usa para cestos de madera rajada — rectangulares, más o menos bajos y con dos asas en el borde- y para cestos de varas finas) eran utilizados para llevar la merienda a los campesinos, siendo cargados sobre la cabeza por las mujeres mientras que, cuando estaban vacíos, los llevaban bajo el brazo (Soeiro 2008-2009: 261).

\footnotetext{
${ }^{27}$ Hay cestos vinculados a actividades marítimas, como la descarga de pescado o su venta, en los mercados de Vila Franca de Xira, Santarém y Setúbal, así como en la estación de Aveiro. En ocasiones, aparecen mujeres vendiendo pescado, como sucede en la citada estación y en el primero de los mercados citados, cuya iconografía tiene precedentes en postales y libros.
} 


\section{REFLEXIÓN FINAL}

De lo visto, pueden destacarse una serie de ideas en este apartado final. La primera es que el hecho de que las imágenes de los paneles de azulejos copien fotografías previas enlaza con la realidad histórica y técnica de los azulejos, es decir, con el recurso de la copia de motivos preexistentes en los grabados. En la época estudiada, y debido al cambio del modelo reproducido, los azulejos "heredan" en cierto sentido el carácter realista que se adjudicaba a las fotografías en el siglo XIX y a comienzos del XX. Como he señalado en varias ocasiones, la copia permite diversas posibilidades gráficas, por lo que no puede hablarse siempre de un servilismo artístico.

El hecho de copiar imágenes preexistentes, y la distancia que separa a ambas imágenes, es sumamente importante desde un punto de vista ideológico ya que a través de este mecanismo se ayuda a la perpetuación de los iconos locales o regionales, que se retroalimentan en cada aparición. Por eso la idea de "presente" que se muestra en los azulejos resulta cuestionable si se hace la ecuación de presente $=$ actualidad. En esos momentos, y junto a los cambios radicales de todo tipo (político, económico, social...) se siguen manteniendo aspectos que enlazan con el pasado. Es desde esta perspectiva, desde la que se pinta el presente, pero no la actualidad visible en el momento mismo en que se realizan los azulejos.

Lo seleccionado claramente remite a una intencionalidad de recoger lo representativo de una zona, lo "típico" y característico, de mostrar lo "pintoresco". Una actitud que incluso se puede afirmar de forma rotunda, como he mencionado al hablar de los cestos de la estación de Pinhão. Se plasma, y se construye, un mundo geográficamente compartimentado y aún no unificado por una modernidad que irradiaba desde las ciudades. Un mundo que, por lo tanto, era obligatoriamente comarcal. Un mundo que participa de lo real, a la vez que se construye simbólicamente. Desde este punto de vista, se puede considerar a los lugares donde se encuentran los azulejos como escaparates en los que presentar una imagen intencionadamente elegida, entre otras muchas posibilidades.

Un simple repaso cuantitativo, nos muestra la existencia de un desequilibrio entre los diversos tipos de cultivo. Un hecho que debe ser matizado, al estar mediatizado por la presencia de cestos, ya que no todos los cultivos requieren de ellos con la misma intensidad y no todas las fases de los mismos tienen igual trascendencia simbólica. No se trata, por tanto, solo del asunto elegido para ser representado, sino de la necesidad de recurrir a los cestos. Por estas causas, resulta abrumadora la presencia de escenas de vendimia, debido tanto a la importancia del cultivo de la viña en esos momentos, como, sobre todo, a la complejidad técnica de la vendimia y el papel jugado por los cestos en ella. Frente a esta faena, otros procesos de trabajo quedan minimizados tanto por el número de lugares en los que se representan como por la menor diversidad de cestos usados en ellos.

También, y tras lo analizado, hay que insistir en la polifuncionalidad de bastantes tipos de cestos que, como he señalado, se usaron para múltiples trabajos agrícolas. Una realidad gráfica que corrobora lo que en la bibliografía sobre el tema ya ha sido indicado repetidamente.

Las imágenes refuerzan — salvo algún caso aislado que no rompe totalmente con el esquema- la asociación de gestos con las connotaciones de género que también ha- 
bían sido apuntadas por diversos autores. Se trata de una evidencia que hay que poner en relación con el carácter realista de estas imágenes debido a su origen fotográfico, lo cual no impide, por supuesto, la carga artística de muchos de los originales.

Finalmente, la multiplicidad de cestos que se han reseñado nos remite a una sociedad que emplea los recipientes de fibras vegetales para todo. Una sociedad que nos muestra el final de un tipo de recursos técnicos que se verían profundamente alterados con la difusión de los recipientes de plástico que se comenzarían a generalizar —algo más tarde en el Portugal rural—, precisamente, en la época posterior a la analizada en este artículo ${ }^{28}$.

\section{BIBLIOGRAFÍA CITADA}

Biel, E. [1902-1908]. A arte e a natureza em Portugal. Edição definitiva. Collecção photograbica de monumentos, costumes e paisagens... Publicada sob a direcção de F. Brütt e Cunha Moraes. Oporto: Emílio Biel e C. ․․ 8 vols. S. p.

Cordeiro de Figueiredo, F. A. 2000. Nacionalismo e pictorialismo na fotografia portuguesa na primeira metade do século XX: o caso exemplar de Domingos Alvão, 446. en http://documenta_pdf.jmir.dyndns.org/F.Figueiredo_Tese\%20Final_PDF_abril2006.pdf [consultado en julio de 2013].

Costa, B. C. C. da y Castro, D. L. de. 1900. Le Portugal au point de vue agricole. Ouvrage publiée sous la direction de... Lisboa: Imprimerie Nationale.

Costa, F. y Serén, M. C. 2004. Illustração Portugueza. Oporto: Ministério da Cultura. Centro Português de Fotografia.

D'Abrunhosa e Mansinho, M. I. (coord.). 2003. Olivais e lagares. Fotografias de Antonio Cezar d'Abrunhoza. S. 1.: Associação Portuguesa de Horticultura.

D'Abrunhosa e Mansinho, M. I. y Azevedo, L. (coords.). 2012. O ciclo do pão. Da sementeira à moagem. Fotografias de Antonio Cezar d'Abrunboza. Castelo Branco: Cámara Municipal de Castelo Branco. Grémio de Letras e Artes.

D'Abrunhosa e Mansinho, M. I. y Delgado, F. (coords.). 2005. A cultura da vinha nos anos 1920/1930 (Beira Baixa). Fotografias de Antonio Cezar d'Abrunboza. S. 1.: Associação Portuguesa de Horticultura.

Dias, J. 1993a. "Maneiras dos homens acartarem em Portugal", Estudos de antropologia. Volume II: 375-383. Lisboa: Imprensa Nacional. Casa da Moeda.

Dias, J. 1993b. "Maneiras das mulheres acartarem em Portugal”, Estudos de antropologia. Volume II: 385-400. Lisboa: Imprensa Nacional. Casa da Moeda.

${ }^{28}$ Desearía agradecer a D. Manuel Novaes Cabral, del Instituto dos Vinhos do Douro e do Por to, por la amable cesión de imágenes de la Casa Alvão del Centro que dirige. Además, mi gratitud, por la ayuda prestada, va dirigida a: María Elisa Sánchez Sanz (Departamento de Psicología y Sociología de la Universidad de Zaragoza); Paulo Ferreira da Costa (Divisão do Património Imóvel, Móvel e Imaterial, Departamento dos Bens Culturais, Direção-Geral do Património Cutural, Lisboa); Leonor Peña Chocarro (Escuela Española de Historia y Arqueología. CSIC, Roma); Javier Ayarza; Nuno Prates (Casa dos Patudos-Museu de Alpiarça); Sofia Leitão (British Council, de Lisboa); Centro de Documentação Manuel Joaquim Afonso, del Museu de Sacavém; Celina Pinto (Museu da Terra de Miranda); y Beatriz Moreira y Sandra Bandeira (Serviço de Documentação e Informação, Instituto dos Vinhos do Douro e do Porto). 
Felgueiras, G. 1932. Espadeladas e Esfolhadas (Nótulas etnográficas). Gaia: Edições Pátria.

França, J-A. 1992. Os anos vinte em Portugal. Lisboa: Presença.

Galhano, F. 1961-1962. "Cestaria de Entre Douro e Minho". Trabalhos de Antropologia e Etnlogia XVIII (3-4): 257-335.

Galhano, F. 1966. "Cestos víndimos. Nota sobre cestaria trasmontana". Revista de Etnografia VI (1): 147-153.

Haudricourt, A-G. 2010. Des gestes aux techniques. Essai sur les techniques dans les sociétés pré-machinistes. París: Éditions de la Maison des sciences de l'homme.

Hengel, J. y Hustinx, V. 1987. Portugal. Painéis de azulejos no século XX. Imagens da vida portuguesa. S. 1.: Caixa Geral de Depósitos.

Kuoni, B. 1981. Cestería tradicional ibérica. Barcelona: Ediciones del Serbal.

Meco, J. 1993. O azulejo em Portugal. Lisboa: Publicações Alfa.

Mingote Calderón, J. L. 2013. "La representación patrimonializada de un país. Portugal en los paneles de azulejos de la primera mitad del siglo XX". Anales del Museo Nacional de Antropología XV: 152-187, en https://sede.educacion.gob.es/publiventa/ detalle.action?cod=14519C [Consulta: 18 junio de 2014].

Mingote Calderón, J. L. e. p. [2014]. "Imágenes del "pueblo" en los paneles de azulejos portugueses de la primera mitad del siglo XX". Anales del Museo Nacional de Antropología XVI.

Rasteiro, J. 1929. Portugal. A Agricultura. Exposição portuguesa em Sevilha. Lisboa: Imprensa Nacional de Lisboa.

Ribeiro, E. 1930. La vertu de l'Osier et du Genêt. Version selon l'original portugais inédit de Claire Jeancourt Gouveia et Francisco da Silva Gouveia. Coimbra: Imprensa da Universidade.

Ribeiro, V. s.f. [1911]. A Terra Portuguesa. (Portugal Pitoresco). Lisboa: Alfredo Davis Encadernador. Biblioteca da Infancia X.

Ribeiro Baptista, P. A. 2010. A Casa Biel e as suas edições fotográficas no Portugal de Oitocentos. Lisboa: Edições Colibri. IHA Estudos de Arte Contemporânea. Faculdade de Ciências Sociais e Humanas. Universidade Nova de Lisboa.

Salinas Calado, R. y Vieira de Almeida, P. 2001. Aspectos azulejares na arquitectura ferroviária portuguesa. S. 1.: Caminhos de Ferro Portugueses, EP.

Santos Silva, M. H. 1961. O cesto. Estudo lingüistico, etnográfico e folclórico. Coimbra: Faculdade de Letras da Universidade de Coimbra. Instituto de Estudos Románicos. Publicado originariamente en Revista Portuguesa de Filologia IX y X (1959 y 1960).

Soeiro, T. 2008-2009. "A cestaria tradicional em Peñafiel". Portugalia XXI-XXX: 253288, y en http://ler.letras.up.pt/uploads/ficheiros/8397.pdf. [Consultado en julio de 2012].

Vicente de Sousa, F. M. y Neto Jacob, J. M. 1985. Portugal no 1. Quartel do Séc. XX documentado pelo Bilhete Postal Ilustrado da $1^{\underline{a}}$ Exposição Nacional de Postais Antigos: Bragança - 1984. Oporto: Câmara Municipal de Bragança.

Veiga de Oliveira, E.; Galhano, F. y Pereira, B. 1975. Actividades agromarítimas em Portugal. Lisboa: Instituto Nacional de Investigação Científica. Centro de Estudos de Etnologia.

Veiga de Oliveira, E.; Galhano, F. y Pereira, B. 1983. Alfaia agrícola portuguesa. Lisboa: Instituto Nacional de Investigação Científica. Centro de Estudos de Etnologia. 
VV. AA. 1932. Le Portugal et son activité économique. Lisboa: Ministère des Affaires Étrangères.

VV. AA. 2000. O azulejo em Portugal no Século XX. Lisboa: Comissão Nacional para as Comemorações dos Descobrimentos Portugueses.

Fecha de recepción: 31 de septiembre de 2013

Fecha de aceptación: 26 de agosto de 2014 